\title{
Interleukin-6 Attenuates Agonist-mediated Calcium Mobilization in Murine Osteoblastic Cells
}

\author{
Jacob Green, Sandra Schotland, Zvi Sella, and Charles R. Kleeman \\ Laboratory of Membrane Biology, Research Institute, Division of Nephrology and Department of Medicine, \\ Cedars-Sinai Medical Center, University of California School of Medicine, Los Angeles, California 90048
}

\begin{abstract}
Interleukin-6 (IL-6) is a multifunctional cytokine which is made by osteoblasts and has diverse effects on bone metabolism. We studied the interaction of $\mathrm{IL}-6$ with the $\mathrm{Ca}^{2+}$ and cAMP signaling systems in the osteoblastic cell line UMR-106 and in primary osteoblastic cultures derived from neonatal rat calvariae. IL-6 did not alter basal intracellular calcium concentration $\left(\left[\mathrm{Ca}^{2+}\right]_{1}\right)$ but inhibited $\mathrm{Ca}^{2+}$ transients induced by parathyroid hormone (PTH), prostaglandin $\mathrm{E}_{2}\left(\mathrm{PGE}_{2}\right)$, and endothelin-1 in both dose- $(100-400 \mathrm{U} / \mathrm{ml})$ and time- $(4-48 \mathrm{~h})$ dependent manners. The effect of the cytokine was abolished by the tyrosine kinase inhibitor, herbimycin $A(50 \mathrm{ng} / \mathrm{ml})$. The IL-6 effect on the $\mathrm{Ca}^{2+}$ message system was related to suppressed production of hormonally induced inositol 1,4,5-triphosphate and inhibition of $\mathrm{Ca}^{2+}$ release from intracellular stores. Hormonally induced calcium entry pathways (estimated by using $\mathrm{Mn}^{2+}$ as a surrogate for $\mathrm{Ca}^{2+}$ ) were not, however, altered by the cytokine. IL-6 did not modulate cAMP generation in osteoblasts. With respect to osteoblast function, IL-6, although having no effect on cell proliferation by itself, greatly enhanced the antiproliferative effect of $\mathrm{PGE}_{2}$ and PTH. Because the production of IL-6 in osteoblasts is stimulated by calciotropic hormones (e.g., PTH and PGE $_{2}$ ), the suppressive effect of the cytokine on hormonally induced $\mathrm{Ca}^{2+}$ transients may serve as an autocrine / paracrine mechanism for modulating the effect of hormones on bone metabolism. ( J. Clin. Invest. 1994. 93:2340-2350.) Key words: interleukin $6 \bullet$ intracellular calcium stores $\bullet$ signal transduction $\bullet$ osteoblasts $\bullet$ inositol triphosphate
\end{abstract}

\section{Introduction}

IL-6 is a recently described multifunctional cytokine which mediates pleiotropic functions in various types of cells (1-15). The biological functions of IL- 6 are mediated through a specific receptor (IL-6R $)^{1}$ the cDNA of which has already been cloned (16-20). The IL-6R system consists of a 80-kD ligand-

Address correspondence to Dr. Jacob Green, Division of Nephrology, Cedars-Sinai Medical Center BB-220, 8700 Beverly Boulevard, Los Angeles, CA 90048.

Received for publication 29 October 1993 and in revised form 12 January 1994.

1. Abbreviations used in this paper: ET-1, endothelin-1; IL-6R, IL-6 receptor; $\mathrm{IP}_{1}$, inositol 4-monophosphate; $\mathrm{IP}_{2}$, inositol 1,4-bisphosphate; $\mathrm{IP}_{3}$, inositol 1,4,5-triphosphate; PKC, protein kinase C; TK, tyrosine kinases.

J. Clin. Invest.

(C) The American Society for Clinical Investigation, Inc.

$0021-9738 / 94 / 06 / 2340 / 11 \quad \$ 2.00$

Volume 93, June 1994, 2340-2350 binding domain and a $130-\mathrm{kD}$ signal-transducing component (gp 130). Binding of IL-6 to its receptor triggers dimerization of $g p 130$ which, in turn, activates intracellular tyrosine kinases (TKs) (20-22).

This article focuses on the role that IL-6 plays in bone metabolism. The cytokine is produced in osteoblasts (23) and its production is regulated by a host of factors including PTH (24, $25), \mathrm{IL}-1, \mathrm{TNF}$, and $1,25(\mathrm{OH})_{2} \mathrm{D}_{3}(26-28)$. Although the role of IL- 6 in the bone microenvironment is not fully elucidated, the majority of evidence suggests that IL- 6 possesses a bone-resorbing activity either by itself or in concert with other osteotropic agents (23). This effect of the cytokine is ascribed primarily to increased formation of osteoclasts from hematopoietic progenitors $(23,25,29)$. Thus, organ cultures containing predominantly mature osteoclasts, do not manifest bone resorption in response to IL-6 $(30,31)$. The role of IL-6 as an osteotropic agent in a clinical setting has been demonstrated in rheumatoid arthritis, where the cytokine mediates juxtaarticular bone resorption (32), in the bone resorption associated with multiple myeloma (5), in osteoporosis associated with estrogen deficiency $(33,34)$, and in the high turnover state of the skeleton in patients with Paget's disease (35). As opposed to the effect of IL- 6 on osteoclasts, the effect of the cytokine on the function of the osteoblast is much less certain. Although produced by both rodent (23) and human osteoblastic cell systems (36), IL-6 has been shown to affect growth and differentiation in rodent osteoblasts $(23,37,38)$ without having any effect on human osteoblasts (36).

In order to shed more light on the role of IL-6 in the metabolism of the osteoblast, we decided to study the interaction of IL-6 with the major signaling pathways activated by calciotropic hormones in osteoblasts, namely, intracellular $\mathrm{Ca}^{2+}$ $\left(\left[\mathrm{Ca}^{2+}\right]_{\mathrm{i}}\right)$ and cAMP. It is now well established that the osteoblast plays a key role in both bone formation and bone resorption processes stimulated by osteotropic agents $(39,40)$. Moreover, the $\mathrm{Ca}^{2+}$ and cAMP messenger systems generated inside the osteoblastic cytosol mediate many of the effects of calciotropic hormones (41-44). Given the in vivo observation of cooperativity between IL- 6 and calciotropic hormones on bone remodeling, it is conceivable that the cytokine impinges on transduction pathways generated by hormones.

For these studies, we used the clonal cell line UMR-106. These cells share many phenotypic features with normal osteoblasts (45). In addition, UMR-106 cells produce IL-6 (25) and also exhibit biological effects in response to the cytokine (37). Because these are transformed osteoblastic cells, we verified the reproducibility of our results by repeating several key experiments in primary cultures from neonatal rat calvariae.

\section{Methods}

Cell culture conditions. The UMR-106 cell line was a generous gift of Dr. T. J. Martin (University of Melbourne, Melbourne, Australia) to 
Dr. T. J. Hahn (Veterans Affairs Medical Center, West Los Angeles, CA), who in turn generously supplied us with these cells. Cells were used between passages 10 and 12 and subpassages 3 and 14. Cells were seeded at a density of $2.5 \times 10^{4}$ cells $/ \mathrm{cm}^{2}$ in tissue culture flasks or multiwell plates and grown at $37^{\circ} \mathrm{C}$ in a humidified $95 \%$ air-5\% $\mathrm{CO}_{2}$ atmosphere in Ham's F12-Dulbecco's modified Eagle's media (1:1) supplemented with $14.3 \mathrm{mM} \mathrm{NaHCO}_{3}, 1.2 \mathrm{mM} \mathrm{L}$-glutamine, $7 \%$ fetal bovine serum, $0.1 \mathrm{mg} / \mathrm{ml}$ streptomycin, and $100 \mathrm{U} / \mathrm{ml}$ penicillin. The cells reached confluence within 6-7 d in culture and were used on days 6-8 of growth.

Primary osteoblast culture was prepared from calvariae of 1-2 dayold Sprague-Dawley rats by using a successive enzymatic digestion method (46). Briefly, calvariae were removed and cleaned from the adherent tissue under a dissecting microscope. The bone tissue was cut into small pieces and digested with a mixture of trypsin/collagenase and bacterial collagenase $(2.0 \mathrm{mg} / \mathrm{ml})$ for $20 \mathrm{~min}$ at $37^{\circ} \mathrm{C}$. The bone pieces were minced with divalent ion-free PBS then resuspended in trypsin/collagenase solution for $40 \mathrm{~min}$ and washed with PBS. After a second 40-min digestion, the pieces were vortexed and filtered through a metal mesh (Millipore Corp., Bedford, MA) and then through $10-\mu \mathrm{m}$ nylon membrane. The filtered solution was mixed with equal volume of PBS and diluted to $30 \mathrm{ml}$ with $\alpha \mathrm{MEM}$. Cells were pelleted by centrifugation at $800 \mathrm{~g}$ for $5 \mathrm{~min}$. The yielded cells were plated in $\alpha \mathrm{MEM}$, supplemented with $10 \%$ FBS, and grown to confluence. Experiments were performed in cells from subpassages 2-5.

Determination of $\left[\mathrm{Ca}^{2+}\right]_{i}$. Changes in cytosolic-free $\mathrm{Ca}^{2+}$ concentration $\left(\left[\mathrm{Ca}^{2+}\right]_{\mathrm{i}}\right)$ were monitored fluorometrically by use of the acetoxymethyl ester (AM) of the $\mathrm{Ca}^{2+}$-sensitive probe fura-2. Cells grown to confluence on $25-\mathrm{mm}$ diam glass coverslips were washed and suspended in a balanced salt solution (BSS) containing (in mM) 140 $\mathrm{NaCl}, 1 \mathrm{MgCl}_{2}, 4 \mathrm{KCl}, 10$ Hepes-Tris, $1.5 \mathrm{CaCl}_{2}, 5$ glucose, and 5 sodium pyruvate, $\mathrm{pH} 7.4$ (adjusted with $1 \mathrm{M} \mathrm{NaOH}$ ). The cells were then loaded with $5 \mu \mathrm{M}$ fura-2 (in dimethyl sulfoxide) for $15-20 \mathrm{~min}$ at $37^{\circ} \mathrm{C}$. Extracellular dye was removed by three washes with BSS. The coverslip with attached cells was then mounted in a perfusion chamber and continuously perfused at a rate of $10-12 \mathrm{ml} / \mathrm{min}$. The perfusate was delivered through an eight way valve to a heat exchanger and then to the chamber and maintained at $37^{\circ} \mathrm{C}$. The recording system included a Diaphot inverted microscope (Nikon Inc., Melville, NJ) equipped with a high numerical aperture Neofluor $\times 100 / 1.3$ numerical aperture (Carl Zeiss, Inc., Thornwood, NY) oil immersion objective. The microscope was attached to a Photon Technology International Deltascan spectrofluorometer (PTI, S. Brunswick, NJ), which provided a dual-wavelength excitation light. To initiate an experiment, cells were bathed in the $\mathrm{Ca}^{2+}$-replete assay buffer, or (where required) in a $\mathrm{Ca}^{2+}$-free buffer that was devoid of $\mathrm{Ca}^{2+}$ and contained $0.1 \mathrm{mM}$ EGTA. The final osmolarity of all solutions was $300 \mathrm{mosmol} / \mathrm{kg} \mathrm{H}_{2} \mathrm{O}$. To evoke a change in $\left[\mathrm{Ca}^{2+}\right]_{i}$, test compounds were added to the assay buffer (where indicated) in a 1:1,000 dilution from a stock solution. Photon emission was monitored at $510 \mathrm{~nm}$ with excitation wavelength alternating between 340 (F340) and $380 \mathrm{~nm}$ (F380). At the end of each experiment, the minimum $\left(R_{\min }\right)$ and maximum $\left(R_{\max }\right)$ ratio of F340 and F380 (R340/380) was determined in BSS containing no added $\mathrm{Ca}^{2+}, 4 \mathrm{mM}$ EGTA and $1 \mu \mathrm{M}$ ionomycin and in BSS containing $10 \mathrm{mM} \mathrm{CaCl}_{2}$ and $1 \mu \mathrm{M}$ ionomycin, respectively. Each coverslip was individually corrected for autofluorescence by $\mathrm{Mn}^{2+}$ quenching and $\left[\mathrm{Ca}^{2+}\right]_{\mathrm{i}}$ was calculated according to the formula (47):

$\left[\mathrm{Ca}^{2+}\right]_{\mathrm{i}}=K_{\mathrm{d}} \mathrm{x},\left[\frac{\left(R-R_{\min }\right)}{\left(R_{\max }-R\right)}\right] \frac{\mathrm{XSf_{2 }}}{S b_{2}}$

where $K_{\mathrm{d}}$ represents the dissociation constant of fura-2 for calcium $(224 \mathrm{nM}), R$ represents the ratio of $\mathrm{F} 340 / \mathrm{F} 380, S f_{2}$ is the F380 intensity obtained from $R_{\min }$ (free fura-2), and $S b_{2}$ is the F380 when the dye is fully saturated with calcium collected during the $R_{\max }$ determination.

Determination of water-soluble inositol phosphates. UMR-106 cells in 12-well plates were labeled with $3 \mu \mathrm{Ci} / \mathrm{ml}$ myo- $\left[{ }^{3} \mathrm{H}\right]$ inositol (Amersham Corp., Arlington Hts, IL) in Trowell's T8 (inositol free) medium supplemented with $15 \mathrm{mM}$ Hepes, $1.2 \mathrm{mM}$ L-glutamine, $2 \%$ fetal calf serum, $100 \mathrm{U} / \mathrm{ml}$ penicillin, and $0.1 \mathrm{mg} / \mathrm{ml}$ streptomycin for $24 \mathrm{~h}$. On the day of the experiment, the unincorporated myo $\left[{ }^{3} \mathrm{H}\right]$ inositol was washed away with serum-free Trowell's T8 medium with the above additives and kept in that same medium for $1 \mathrm{~h}$ in the presence of 10 $\mathrm{mM} \mathrm{LiCl}$. Cells were stimulated with various agonists for the designated times. The reaction was terminated by the aspiration of the medium, followed by two $10 \%$ trichloroacetic acid washes. The washes were pooled, and trichloroacetic acid was extracted with water-saturated diethyl ether. The ether extracts were loaded onto glass woolplugged Pasteur pipette columns containing $\sim 2 \mathrm{~g}$ of anion exchange resin (AG 1-X8 formate, Bio-Rad Laboratories, Richmond, CA). Inositol 4-monophosphate ( $\left.\mathrm{IP}_{1}\right)$, inositol 1,4-bisphosphate $\left(\mathrm{IP}_{2}\right)$, and inositol 1,4,5-triphosphate $\left(\mathrm{IP}_{3}\right)$ were sequentially eluted from the columns by increasing concentrations of ammonium formate, according to the method of Berridge et al. (48). Elution fractions of $2 \mathrm{ml}$ each were diluted into liquid scintillation fluid and counted in a $\beta$ counter. Data are expressed as total counts per minute of 6-ml eluates for each inositol phosphate metabolite per $10^{6}$ cells.

Determination of cellular cAMP levels. Determination of cellular cAMP levels was done in culture plates containing 24 multiwells per plate. Cells preincubated with IL- 6 or vehicle (PBS $+0.1 \%$ albumin) were acutely (from $5 \mathrm{~min}$ to $2 \mathrm{~h}$ ) stimulated with agonists dissolved in $1 \mathrm{ml}$ of BSS solution at $37^{\circ} \mathrm{C}$ in the presence of $0.2 \mathrm{mM}$ 3-isobutyl-1-methylxanthine. The reaction was terminated by aspirating the medium containing the stimulant and then adding $0.5 \mathrm{ml} \mathrm{L}$ propanol to extract the cAMP from the cell layer. The cell layers were then kept at $4^{\circ} \mathrm{C}$ for $1 \mathrm{~h}$. The propanol extract was removed to glass tubes, the propanol was evaporated under a stream of nitrogen gas, and the dried extract was kept at $-70^{\circ} \mathrm{C}$ until assay. Before assay, the extract was reconstituted with sodium acetate buffer, pH 6.2. Assay of cAMP was carried out by RIA with minor modification. [ $\left.{ }^{125} \mathrm{I}\right]-$ Succinyltyrosine ester of cAMP (ICN, Irvine, CA) $(10,000 \mathrm{cpm} / 100$ $\mu \mathrm{l})$ was utilized. Antigen-antibody precipitation was done by $100 \%$ ethanol. Results are expressed as picomoles of cAMP per $10^{6}$ cells.

Determination of cell proliferation. Cell proliferation was assessed by the incorporation of $\left[{ }^{3} \mathrm{H}\right]$ thymidine. Briefly, cells were grown in 24-well plates. $22 \mathrm{~h}$ before experimentation, the medium was changed to serum-free Ham's F-12-DME. $3 \mathrm{~h}$ before the harvest, cells were pulsed with $0.2 \mu \mathrm{Ci} / \mathrm{ml}\left[{ }^{3} \mathrm{H}\right]$ thymidine $(6.7 \mathrm{Ci} / \mathrm{mmol})$. Cells were harvested by three PBS washes to remove unincorporated label followed by two washes with $10 \%$ trichloroacetic acid. The cell layers were solubilized in $1 \mathrm{~N} \mathrm{NaOH}$, and aliquots of the solubilized cells were diluted into liquid scintillation fluid after neutralization with $\mathrm{HCl}$ and counted in a $\beta$-counter. Data are expressed as counts per minute per well. Cell counts were performed by releasing cells with trypsin-EDTA and counting with a hemacytometer.

Statistics. Results are expressed as means \pm SE. Nonlinear square curve fitting was used to assess dose-response curves to estimate mean half-maximally effective $\left(E_{50}\right)$ and maximally effective concentrations of agonist with $67 \%$ confidence limits, assuming highly correlated asymmetric variance spaces. One- and two-way analyses of variance to test for differences among treatment means were performed as indicated where appropriate. Each experiment was performed at least four times with separate batches of cells to confirm reproducibility of the results.

Reagents and hormones. Recombinant murine IL- 6 was obtained from R \& D Systems (Minneapolis, MN). This preparation had a specific activity of $1 \times 10^{7} \mathrm{U} / \mathrm{mg}$, was $>97 \%$ pure and had $<0.1 \mathrm{ng}$ of endotoxin per microgram of cytokine. Lyophilized IL-6 was reconstituted in PBS containing $0.1 \%$ BSA to yield a working stock solution of $1 \mu \mathrm{g} / \mathrm{ml}$. PGE 2 was purchased from The Upjohn Co. (Kalamazoo, MI). Endothelin-1 (ET-1) was obtained from Peptide Institute (Osaka, Japan) and bovine PTH (1-34) was from Peninsula Laboratories (San Carlos, CA). Fura-2/AM was obtained from Molecular Probes Inc. (Eugene, OR) and PMA was purchased from Calbiochem Corp. (San Diego, CA). Herbimycin A was from GIBCO (Grand Island, NY). Stock solution of the drug was made in $100 \%$ DMSO and diluted with the culture medium before addition to cells. The culture medium con- 
taining the equivalent concentrations of DMSO served as vehicle controls.

\section{Results}

IL-6 effect on agonist-induced $\mathrm{Ca}^{2+}$ transients. $\left[\mathrm{Ca}^{2+}\right]_{\mathrm{i}}$ in osteoblasts can be elevated either by opening of a plasma membrane $\mathrm{Ca}^{2+}$ channel $(49,50)$ or through release of $\mathrm{Ca}^{2+}$ from intracellular stores following hormonal activation of phospholipase $\mathrm{C}$ and phosphatidylinositol breakdown $(44,51,52)$ Figs. 1, 2, and 3 describe the effect of IL- 6 on $\mathrm{Ca}^{2+}$ transients induced by acute stimulation with three calciotropic hormones known to elevate $\left[\mathrm{Ca}^{2+}\right]_{i}$ by both mechanisms.

Under control conditions (vehicle-treated cells, Fig. $1 \mathrm{~A}$ ) acute stimulation of UMR-106 cells with $10^{-8}$ bPTH (1-34) in the presence of $1.5 \mathrm{mM} \mathrm{Ca}^{2+}$ in the extracellular buffer elicited an instantaneous rise in $\left[\mathrm{Ca}^{2+}\right]_{\mathrm{i}}$ from a basal value of $114 \pm 8$ $\mathrm{nM}$ to a peak value of $185 \pm 9 \mathrm{nM}$. When cells were preincubated for $24 \mathrm{~h}$ with $200 \mathrm{U} / \mathrm{ml} \mathrm{IL-6}$ (Fig. $1 \mathrm{~B}$ ), resting $\left[\mathrm{Ca}^{2+}\right]_{\mathrm{i}}$ was not altered $\left(\left[\mathrm{Ca}^{2+}\right]_{\mathrm{i}}=116 \pm 12 \mu \mathrm{M} ; P>0.05\right.$ vs. control $)$. However, PTH-induced $\mathrm{Ca}^{2+}$ transient was significantly atten-
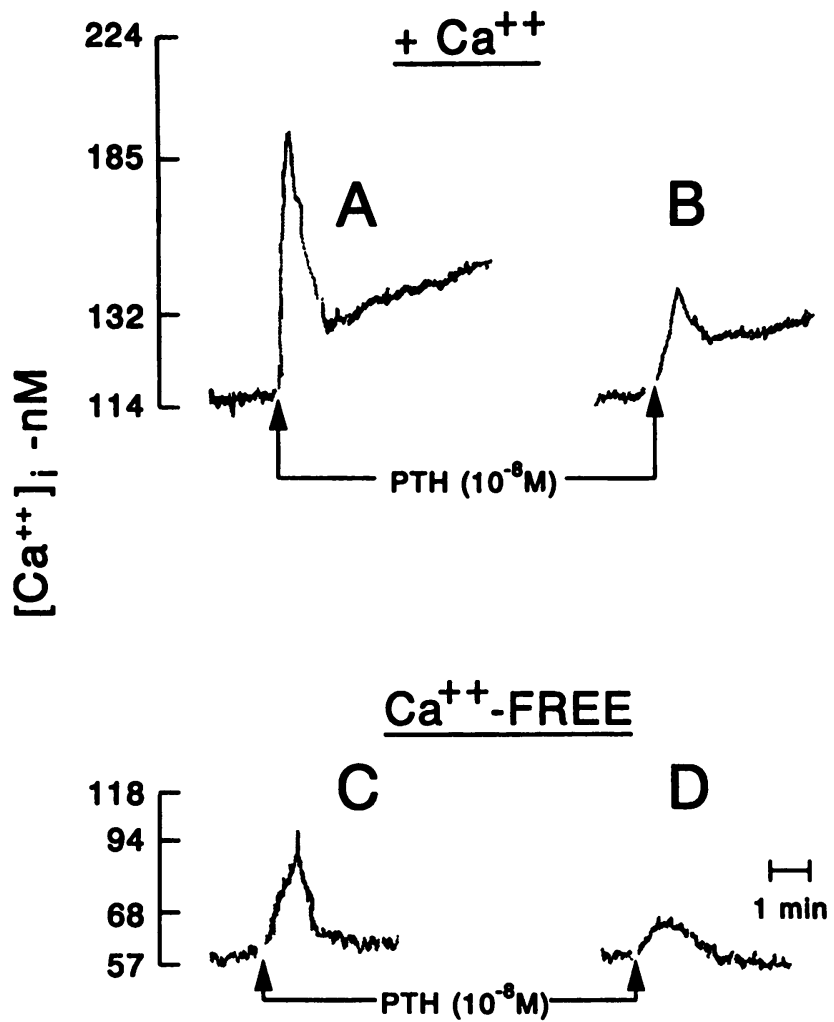

Figure 1. IL-6 effect on PTH-induced $\mathrm{Ca}^{2+}$ transients. UMR-106 cells were preincubated for $24 \mathrm{~h}$ in serum-free DME containing either vehicle alone $(A$ and $C$ ) or $200 \mathrm{U} / \mathrm{ml} \mathrm{IL-6} \mathrm{(} B$ and $D$ ). On the day of the experiment, cells were loaded with the $\mathrm{Ca}^{2+}$ indicator fura-2 and mounted onto stage of a Nikon Diaphot microscope attached to a Deltascan spectrofluorometer as described in Methods. Cells were perfused with BSS pH 7.4 at $37^{\circ} \mathrm{C}$. PTH $(1-34)$ was then added acutely to the cells at a dose of $10^{-8} \mathrm{M}$ (arrows) and fluorescence was recorded. Cytosolic $\mathrm{Ca}^{2+}$ concentration $\left(\left[\mathrm{Ca}^{2+}\right]_{i}\right)$ was calculated after calibration of the signal. Experiment was carried out both in the presence of $1.5 \mathrm{mM} \mathrm{CaCl}_{2}$ in the bathing solution $(A$ and $B)$ and in $\mathrm{Ca}^{2+}$-free solution containing $0.1 \mathrm{mM}$ EGTA $(C$ and $D)$. This experiment represents 1 of 12 experiments with similar results. uated in IL-6-treated cells (peak $\left[\mathrm{Ca}^{2+}\right]_{\mathrm{i}}=132 \pm 6 \mathrm{nM} ; P$ $<0.01$ vs. control).

To evaluate the contribution of extracellular calcium to the effect of IL- 6 on PTH-induced $\mathrm{Ca}^{2+}$ transients, we repeated the experiment while bathing the cells in $\mathrm{Ca}^{2+}$-free medium. Any residual $\mathrm{Ca}^{2+}$ in the buffer was removed by the addition of EGTA. Under these conditions, resting $\left[\mathrm{Ca}^{2+}\right]_{\mathrm{i}}$ falls significantly because, in the absence of extracellular $\mathrm{Ca}^{2+},\left[\mathrm{Ca}^{2+}\right]_{\mathrm{i}}$ is pumped out from the cytosol by the plasma membrane $\mathrm{Ca}^{2+}$ adenosine triphosphatase at a faster rate as compared with when there is $\mathrm{Ca}^{2+}$ in the media. Thus, after 4-5 min of incubation in $\mathrm{Ca}^{2+}$-free media and in the presence of EGTA, $\left[\mathrm{Ca}^{2+}\right]_{\mathrm{i}}$ stabilized at a value of $58 \pm 6 \mathrm{nM}$ (Fig. $1 C$ and $D$ ). This value was not altered by preincubation of the cells with $200 \mathrm{U} / \mathrm{ml}$ of IL-6 for $24 \mathrm{~h}$. Acute exposure of the cells to $10^{-8} \mathrm{M}$ PTH, elicited an immediate $\left[\mathrm{Ca}^{2+}\right]_{\mathrm{i}}$ rise to a value of $94 \pm 4 \mathrm{nM}$ (Fig. $1 C$ ). In the absence of $\mathrm{Ca}^{2+}$ in the extracellular medium, this $\mathrm{Ca}^{2+}$ transient reflects $\mathrm{Ca}^{2+}$ release from intracellular stores. This component of $\left[\mathrm{Ca}^{2+}\right]_{i}$ rise was significantly blunted by preincubation for $24 \mathrm{~h}$ with $200 \mathrm{U} / \mathrm{ml} \mathrm{IL-6}\left(\left[\mathrm{Ca}^{2+}\right]_{\mathrm{i}}=68 \pm 3\right.$ nM; $P<0.01$ vs. control) (Fig. $1 D$ ).

Fig. 2 describes the effects of IL-6 on PGE $\mathrm{PG}_{2}$-induced $\left[\mathrm{Ca}^{2+}\right]_{i}$ response in UMR-106 cells. While not altering basal $\left[\mathrm{Ca}^{2+}\right]_{\mathrm{i}}$, $24 \mathrm{~h}$ of preincubation with $200 \mathrm{U} / \mathrm{ml}$ IL-6 (Fig. 2, $B$ and $D$ ) significantly attenuated $\mathrm{PGE}_{2}(1 \mu \mathrm{M})$-induced $\left[\mathrm{Ca}^{2+}\right]_{\mathbf{i}}$ rise both in the presence and absence of extracellular $\mathrm{Ca}^{2+}$. In the presence of $1.5 \mathrm{mM} \mathrm{Ca}^{2+}$ in the extracellular buffer (Fig. 2, $A$ and $B$ ), peak $\left[\mathrm{Ca}^{2+}\right]_{\mathrm{i}}$ was $283 \pm 17$ and $165 \pm 11 \mathrm{nM}$ in control and IL-6-treated cells, respectively $(P<0.01)$. In $\mathrm{Ca}^{2+}$-free conditions, (Fig. 2, $C$ and $D$ ) peak $\left[\mathrm{Ca}^{2+}\right]_{\mathrm{i}}$ was $156 \pm 5$ and $94 \pm 2 \mathrm{nM}$ in control and IL-6-treated cells respectively $(P$ $<0.005)$.

Endothelin, the most potent vasoconstrictor agent, has also been shown to activate plasma membrane receptors in osteoblastic cells and to induce $\left[\mathrm{Ca}^{2+}\right]_{\mathrm{i}}$ responses in these cells (52). The effect of IL- 6 on $\mathrm{Ca}^{2+}$ transients induced by $10^{-8} \mathrm{M}$ ET-1 in UMR-106 cells is described in Fig. 3. Once again, the cytokine significantly blunts $\left[\mathrm{Ca}^{2+}\right]_{i}$ increments induced by ET-1 either in the presence of (Fig. 3, $A$ and $B$ ) or absence (Fig. 3, $C$ and $D$ ) of $\mathrm{Ca}^{2+}$ in the extracellular medium. Thus, 24-h incubation with $200 \mathrm{U} / \mathrm{ml}$ IL-6 brings about 50-60\% suppression of $\mathrm{Ca}^{2+}$ transients.

$I L-6$ effect in cells treated with indomethacin. In view of the fact that in cultured osteoblastic cells, IL-6 can stimulate the production of $\mathrm{PGE}_{2}$ (37), we studied the effect of IL-6 on agonist-stimulated $\left[\mathrm{Ca}^{2+}\right]_{\mathrm{i}}$ rise in UMR-106 cells preincubated for $24 \mathrm{~h}$ with $1 \mu \mathrm{M}$ indomethacin. The suppressive effect of $24 \mathrm{~h}$ of pretreatment with IL- 6 on the $\left[\mathrm{Ca}^{2+}\right]_{i}$ signal in response to PTH, PGE 2 , and ET-1 was not altered by indomethacin (data not shown), thus indicating that the effect of the cytokine was independent of $\mathrm{PGE}_{2}$ production.

IL-6 effect in the presence of TK inhibitors. IL-6 has been shown to activate intracellular TKs as its main signal transduction $(21,22)$. We, therefore, tested the possibility that the suppressive effect of IL-6 on hormonal mediated $\mathrm{Ca}^{2+}$ signals is mediated through the activation of intracellular TK. Toward that end, we studied the effect of IL-6 on $\mathrm{Ca}^{2+}$ transients in vehicle (DMSO)-treated cells as compared to cells pretreated for $24 \mathrm{~h}$ with $50 \mathrm{ng} / \mathrm{ml}$ herbimycin A. This antibiotic drug has been shown to inhibit a number of intracellular TKs including the src TK, while having no effect on serine/threonine kinase, protein kinase $A$, and protein kinase $C(53)$. Fig. 4 shows that 

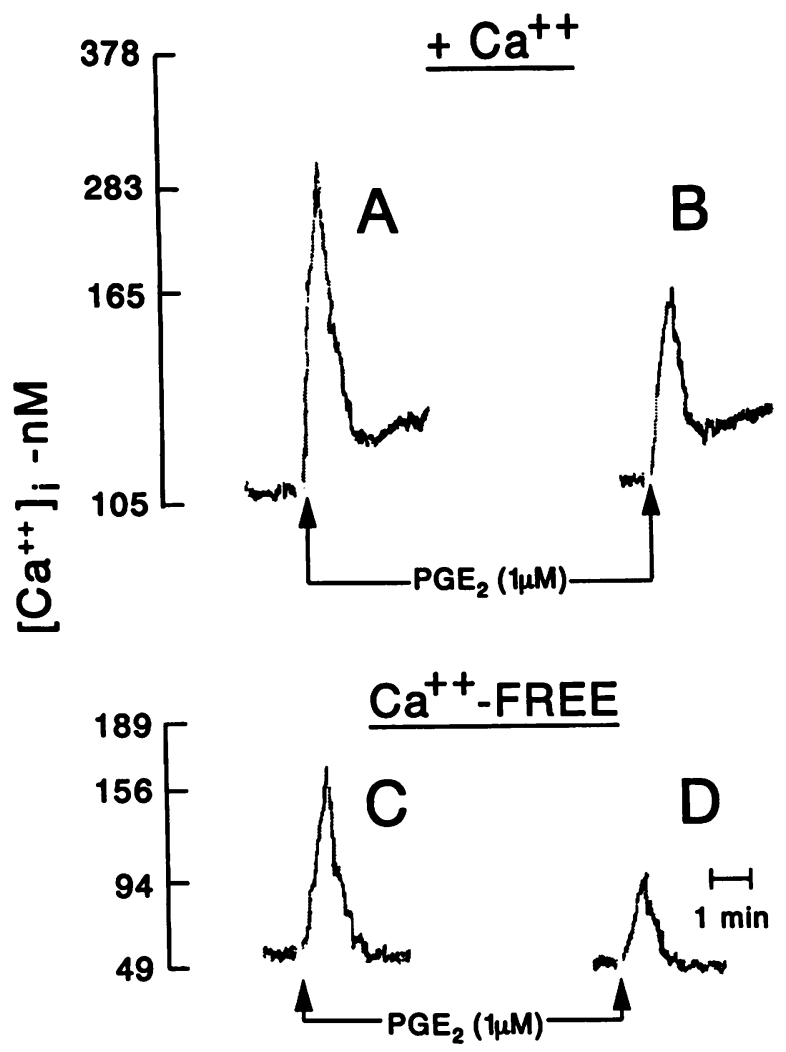

Figure 2. IL-6 effect on $\mathrm{PGE}_{2}$-induced $\mathrm{Ca}^{2+}$ transients. UMR-106 cells were preincubated for $24 \mathrm{hr}$ in serum-free DME containing either vehicle alone ( $A$ and $C$ ) or $200 \mathrm{U} / \mathrm{ml} \mathrm{IL-6} \mathrm{(} B$ and $D)$. On the day of the experiment, cells were loaded with the $\mathrm{Ca}^{2+}$ indicator fura-2 and perfused with BSS as described in Methods. $\mathrm{PGE}_{2}(1 \mu \mathrm{M})$ was added acutely to the cells (arrows) and fluorescence was recorded. Cytosolic $\mathrm{Ca}^{2+}$ concentration $\left(\left[\mathrm{Ca}^{2+}\right]_{\mathrm{i}}\right)$ was calculated after calibration of the signal. This experiment was carried out both in the presence of $1.5 \mathrm{mM} \mathrm{CaCl}_{2}$ in the bathing solution $(A$ and $B)$ and in $\mathrm{Ca}^{2+}$-free solution containing $0.1 \mathrm{mM}$ EGTA $(C$ and $D)$. This experiment represents one of nine experiments with similar results.

in vehicle-treated cells IL- 6 causes inhibition of $\mathrm{Ca}^{2+}$ transients induced by either ET-1 or PGE 2 as seen before. However, in cells pretreated with herbimycin $\mathrm{A}$, while the drug itself did not have an effect on hormonally induced $\mathrm{Ca}^{2+}$ rise, it completely abrogated the inhibitory effect of IL- 6 on $\mathrm{Ca}^{2+}$ signals generated by ET-1 and PGE 2 . We also used as a control the drug tyrphostin (RG50863) which is another TK inhibitor but with higher specificity for receptor TKs (e.g., EGF receptor) as opposed to intracellular TKs (54). Pretreatment of the cells for 24 $\mathrm{h}$ with $50 \mu \mathrm{g} / \mathrm{ml}$ tyrphostin did not have any influence on IL-6induced suppression of $\left[\mathrm{Ca}^{2+}\right]_{\mathrm{i}}$ rise (not shown). Neither of the TK inhibitors induced cell toxicity, as judged by Trypan blue exclusion assay, by lack of an effect on cell number and lack of detachment of the cells from the plastic culture dishes.

IL-6 effect on $\mathrm{Ca}^{2+}$ transients in calvarial osteoblasts. Fig. 5 describes the effect of IL- 6 on hormonally induced $\mathrm{Ca}^{2+}$ rise in primary osteoblastic cultures derived from neonatal rat calvariae. The cytokine effect in this cell preparation follows the same pattern as described for UMR-106 cells. Thus, under control conditions, acute stimulation of the cells with ET-1 $\left(10^{-8} \mathrm{M}\right)$ and $\mathrm{PGE}_{2}(1 \mu \mathrm{M})$ elicited $\left[\mathrm{Ca}^{2+}\right]_{i}$ rise to the level of $675 \pm 11$ and $364 \pm 8 \mathrm{nM}$, respectively. Preincubation of the cells for $24 \mathrm{~h}$ with $200 \mathrm{U} / \mathrm{ml}$ IL-6 significantly attenuated the $\left[\mathrm{Ca}^{2+}\right]_{\mathrm{i}}$ peak

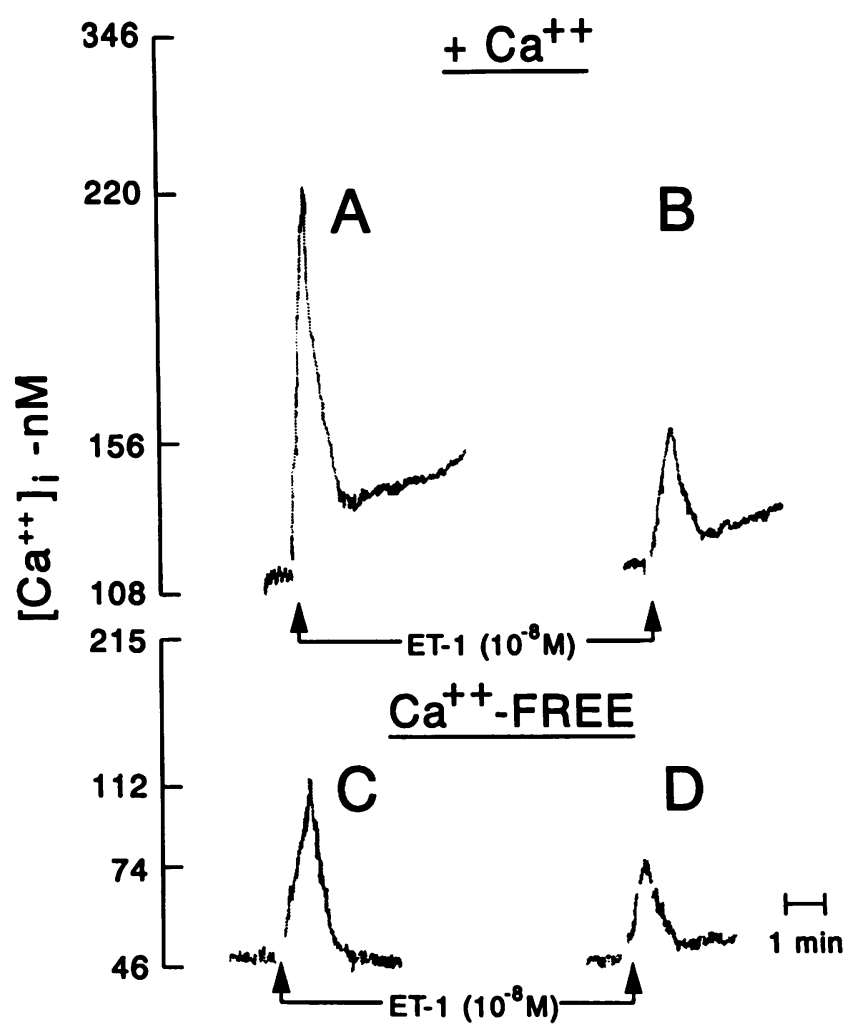

Figure 3. IL-6 effect on endothelin-induced $\mathrm{Ca}^{2+}$ transients. UMR106 cells were preincubated for $24 \mathrm{~h}$ in serum-free DME containing either vehicle alone ( $A$ and $C$ ) or $200 \mathrm{U} / \mathrm{ml} \mathrm{IL-6}(B$ and $D)$. On the day of the experiment, cells were loaded with the $\mathrm{Ca}^{2+}$ indicator fura-2 and perfused with BSS as described in Methods. ET-1 $\left(10^{-8}\right.$ $\mathrm{M}$ ) was added acutely to the cells (arrows) and fluorescence was recorded. Cytosolic $\mathrm{Ca}^{2+}$ concentration $\left(\left[\mathrm{Ca}^{2+}\right]_{\mathrm{i}}\right)$ was calculated after calibration of the signal. This experiment was carried out both in the presence of $1.5 \mathrm{mM} \mathrm{CaCl}_{2}$ in the perfusing solution $(A$ and $B)$ and in $\mathrm{Ca}^{2+}$-free solution containing $0.1 \mathrm{mM}$ EGTA $(C$ and $D)$. This experiment represents 1 of 10 experiments with similar results.

after hormonal stimulation ( $321 \pm 5$ and $224 \pm 12 \mathrm{nM}$, for ET- 1 and $\mathrm{PGE}_{2}$, respectively; $P<0.01 \mathrm{IL}-6$ vs. control for each hormone). Also shown in the figure is the effect of the TK inhibitor, herbimycin A. Similar to UMR-106 cells, in calvarial osteoblasts as well, herbimycin A did not have an effect of its own on hormonally induced $\mathrm{Ca}^{2+}$ transients, but it totally

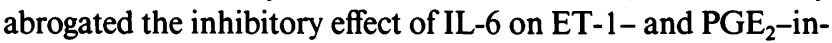
duced $\mathrm{Ca}^{2+}$ rise.

IL-6 effect on $\mathrm{Ca}^{2+}$ influx vs. $\mathrm{Ca}^{2+}$ release. Thus far, we have demonstrated that IL- 6 attenuates $\left[\mathrm{Ca}^{2+}\right]_{i}$ signals after stimulation with PTH, PGE 2 , and ET-1. To distinguish between an effect of IL- 6 on $\mathrm{Ca}^{2+}$ entry across the plasma membrane vs. an effect on $\mathrm{Ca}^{2+}$ release from internal organelles we used manganese $\left(\mathrm{Mn}^{2+}\right)$ as a surrogate for $\mathrm{Ca}^{2+} . \mathrm{Mn}^{2+}$ uses the same influx channels as $\mathrm{Ca}^{2+}$ and has a very high affinity for fura- 2 and binding of $\mathrm{Mn}^{2+}$ to the fura-2 molecule quenches its fluorescence (55). Thus, changes in fura-2 fluorescence induced by $\mathrm{Mn}^{2+}$ can be used to estimate $\mathrm{Ca}^{2+}$ entry across the plasma membrane. In the experiment described in Fig. 6, UMR-106 cells were exposed to $\mathrm{Ca}^{2+}$-free media (containing EGTA) with (Fig. 6, $C$ and $D$ ) or without (Fig. 6, $A$ and $B$ ) 10 $\mu \mathrm{M} \mathrm{MnCl}$. Acute stimulation of the cells with $\mathrm{PGE}_{2}$ evoked a $\mathrm{Ca}^{2+}$ transient which under the $\mathrm{Ca}^{2+}$-free conditions is due to 


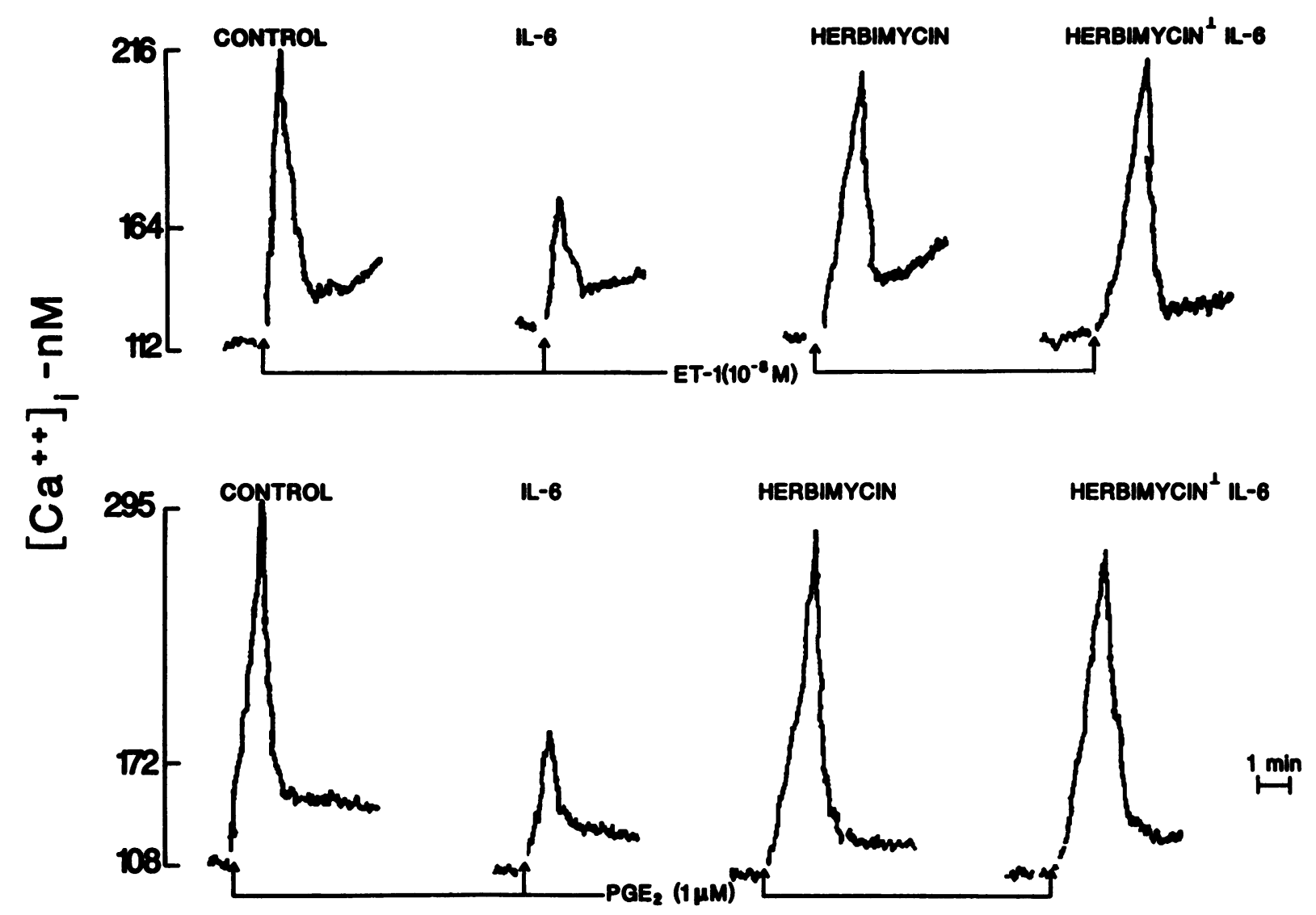

Figure 4. Herbimycin A abrogates the inhibitory effect of IL-6 on hormonally induced $\mathrm{Ca}^{2+}$ transients. UMR-106 cells were preincubated for 24 $\mathrm{h}$ in serum-free DME containing the following additives: (a) DMSO (1:1,000 dilution)-control. (b) DMSO $+200 \mathrm{U} / \mathrm{ml} \mathrm{IL}-6$. (c) Herbimycin A $(50 \mathrm{ng} / \mathrm{ml})$. (d) Herbimycin A $(50 \mathrm{ng} / \mathrm{ml})+200 \mathrm{U} / \mathrm{ml} \mathrm{IL-6.} \mathrm{On} \mathrm{the} \mathrm{day} \mathrm{of} \mathrm{the} \mathrm{experiment,} \mathrm{cells} \mathrm{were} \mathrm{loaded} \mathrm{with} \mathrm{fura-} 2$ and perfused with BSS containing $1.5 \mathrm{mM} \mathrm{CaCl} 2$. ET-1 $\left(10^{-8} \mathrm{M}\right)$ or $\mathrm{PGE}_{2}(1 \mu \mathrm{M})$ were added acutely as indicated by the arrows and fluorescence was recorded. This experiment represents one of five experiments with similar results. Similar results were also obtained when the response to (1-34) PTH (10 ${ }^{-8}$ M) was tested.

$\mathrm{Ca}^{2+}$ mobilization from intracellular stores. The $\left[\mathrm{Ca}^{2+}\right]_{\mathrm{i}}$ rise was significantly attenuated by $24-\mathrm{h}$ incubation with $200 \mathrm{U} / \mathrm{ml}$ IL-6 (Fig. 6, $B$ and $D$ ). The IL-6 effect on $\left[\mathrm{Ca}^{2+}\right]_{\mathrm{i}}$ increments was the same regardless of the absence (Fig. $6, A$ and $B$ ) or presence (Fig. 6, $C$ and $D$ ) of $\mathrm{MnCl}_{2}$. The initial fast rise in fura-2 fluorescence was followed by fluorescence quenching signifying $\mathrm{Mn}^{2+}$ influx (Fig. 6,C and $D$ ). Pretreatment with IL- 6 did not have any effect on the $\mathrm{Mn}^{2+}$ induced quenching of the fura-2 fluorescence. It appears, therefore, that the cytokine affects only $\mathrm{Ca}^{2+}$ release from intracellular stores without altering $\mathrm{Ca}^{2+}$ influx. The $\mathrm{Mn}^{2+}$ induced fluorescence quenching (Fig. 6, $C$ and $D$ ) could be blocked by $10 \mu \mathrm{M} \mathrm{La}^{3+}$ (data not shown). The $\mathrm{Mn}^{2+}$ experiments as performed with $\mathrm{PGE}_{2}$ were also carried out with ET-1. Similar qualitative results were obtained.

Effect of IL-6 on protein kinase C (PKC)- and depolarization-activated $\mathrm{Ca}^{2+}$ channels. The effect of IL- 6 on nonhormonal $\mathrm{Ca}^{2+}$ entry mechanisms (i.e., plasma membrane $\mathrm{Ca}^{2+}$ channels) is demonstrated in Fig. 7. We have recently shown that in addition to hormonally mediated $\mathrm{Ca}^{2+}$ channel, UMR106 cells also possess $P K C$ activated and depolarization $(=$ voltage)-activated $\mathrm{Ca}^{2+}$ channels $(49,50)$. When cells were acutely stimulated with $1 \mu \mathrm{M}$ of the phorbol ester PMA, an activator of $\mathrm{PKC},\left[\mathrm{Ca}^{2+}\right]_{\mathrm{i}}$ rose from a resting value of $134 \pm 6$ $\mathrm{nM}$ to a peak value of $386 \pm 12 \mathrm{nM}$ (Fig. $7 A$ ). In cells treated for $24 \mathrm{~h}$ with $200 \mathrm{U} / \mathrm{ml} \mathrm{IL-6}$ (Fig. $7 a$ ), the acute $\left[\mathrm{Ca}^{2+}\right]_{\mathrm{i}}$ response to the stimulation of PKC was not altered (peak $\left[\mathrm{Ca}^{2+}\right]_{\mathrm{i}}=392 \pm 9 \mathrm{nM} ; P=\mathrm{NS}$ vs. control $)$.

To study the effect of IL-6 on the properties of the depolarization-activated $\mathrm{Ca}^{2+}$ channel, we acutely exposed the cells to $\mathrm{BaCl}_{2}$ in $\mathrm{Ca}^{2+}$-free media (Fig. 7, $\mathrm{B}$ and $b$ ). Barium blocks the exit of potassium from the cells, thereby causing membrane depolarization. Cell depolarization activates a voltage-gated channel through which barium (in this case, replacing $\mathrm{Ca}^{2+}$ ) can enter the cell. The entry of barium is detected by its binding to fura-2, which elicits a fluorescent signal. Because accurate calculation of the $K_{\mathrm{d}}$ of fura-2 to barium is fraught with great difficulty, it was impossible to calibrate the barium signal. It is, however, clear that, on a qualitative basis, barium entered the cells at a rate and extent that were similar in both control (Fig. $7 B$ ) and IL-6-treated cells (Fig. 7 b).

The data presented in Figs. 6 and 7, when taken together, indicate that IL-6 modulates $\left[\mathrm{Ca}^{2+}\right]_{\mathrm{i}}$ transients that are stimulated by hormones. The cytokine does not affect plasma membrane $\mathrm{Ca}$ channels (i.e., hormonal, PKC activated, or voltage activated).

Dose dependency of $\mathrm{IL}-6$ effect on $\left[\mathrm{Ca}^{2+}\right]_{i}$ signals. Fig. 8 shows that the suppressive effect of IL-6 on hormonally induced $\mathrm{Ca}^{2+}$ transients was dose dependent. The effect of the cytokine on $\mathrm{PGE}_{2}(1 \mu \mathrm{M})$ induced $\left[\mathrm{Ca}^{2+}\right]_{\mathrm{i}}$ rise was maximal at 


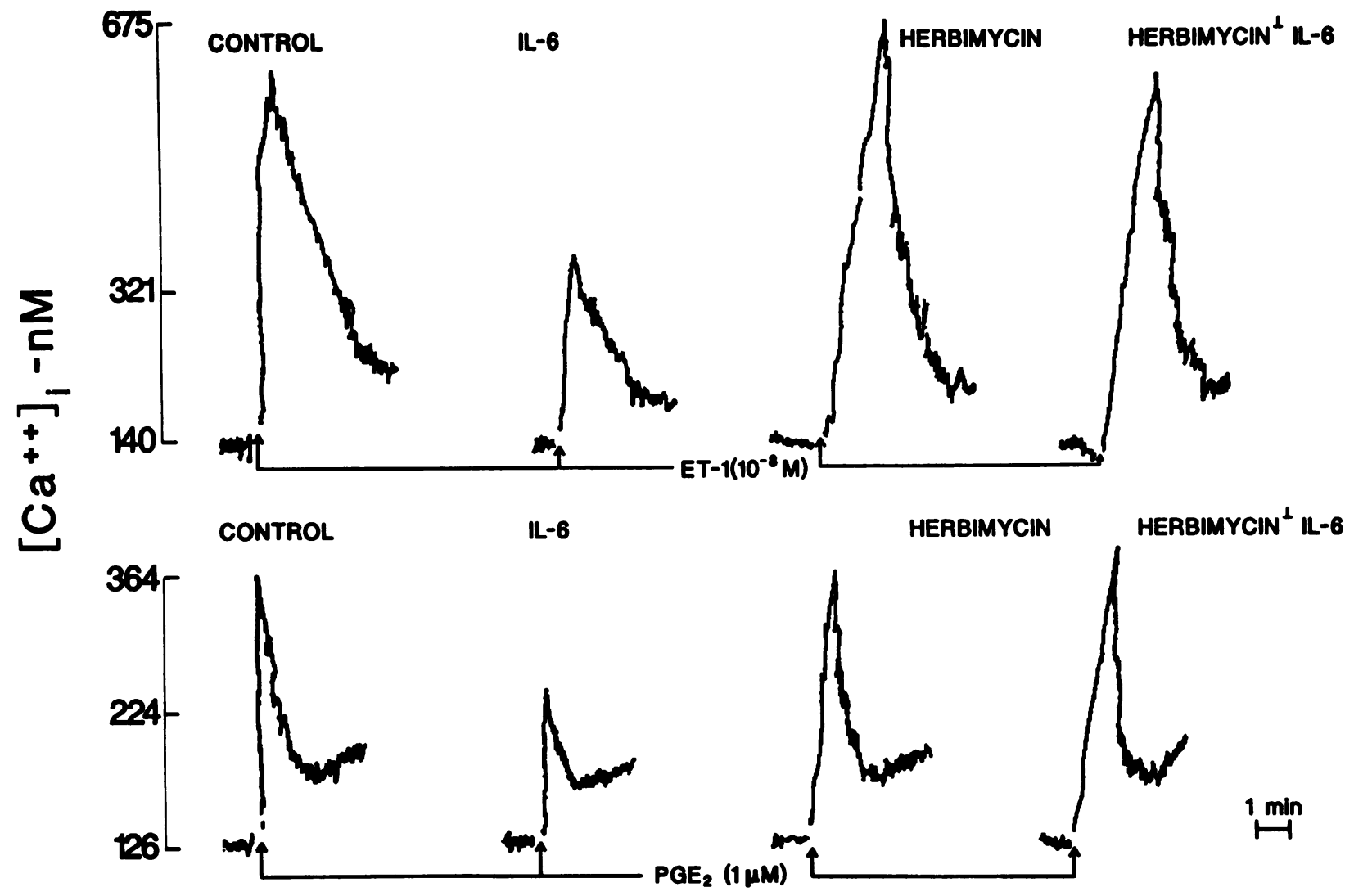

Figure 5. IL-6 effect on hormonally induced $\left[\mathrm{Ca}^{2+}\right]_{\mathrm{i}}$ rise in primary osteoblastic cultures: effect of herbimycin A. Primary osteoblast cultures were prepared from neonatal rat calvariae as described in Methods. Cells in subpassages 2-5 were cultured in $\alpha \mathrm{MEM}$ and $24 \mathrm{~h}$ before the experiment, cells were preincubated with the following additives: (a) DMSO (1:1,000 dilution)-control. (b) DMSO + 200 U/ml IL-6. (c) Herbimycin A $(50 \mathrm{ng} / \mathrm{ml})$. (d) Herbimycin A $(50 \mathrm{ng} / \mathrm{ml})+200 \mathrm{U} / \mathrm{ml} \mathrm{IL-6.} \mathrm{On} \mathrm{the} \mathrm{day} \mathrm{of} \mathrm{the} \mathrm{experiment,} \mathrm{cells} \mathrm{were} \mathrm{loaded} \mathrm{with} \mathrm{fura-} 2$ and acutely stimulated with ET-1 $\left(10^{-8} \mathrm{M}\right)$ or $\mathrm{PGE}_{2}(1 \mu \mathrm{M})$ as indicated by arrows. Fluorescence was recorded and $\left[\mathrm{Ca}^{2+}\right]_{\mathrm{i}}$ calculated as described above. This experiment is one of three similar experiments.

$400 \mathrm{U} / \mathrm{ml}$ ( $\sim 90 \%$ suppression after $24 \mathrm{~h}$ of preincubation $).$ $200 \mathrm{U} / \mathrm{ml} \mathrm{IL-6,} \mathrm{which} \mathrm{is} \mathrm{the} \mathrm{dose} \mathrm{most} \mathrm{commonly} \mathrm{used} \mathrm{in} \mathrm{our}$ studies, produced $60-70 \%$ attenuation of the $\mathrm{Ca}^{2+}$ transient induced by $\mathrm{PGE}_{2}$. A qualitatively similar dose response was obtained when IL- 6 effect on PTH-evoked $\left[\mathrm{Ca}^{2+}\right]_{i}$ signals was studied (data not shown). The IL-6 doses needed to have an effect on $\left[\mathrm{Ca}^{2+}\right]_{i}$ responses fall in the value range for IL-6 produced endogenously by osteoblasts in response to other cytokines and to PTH $(23,25)$. It is, therefore, conceivable that the IL-6 effect described here bears a physiological significance.

Time course for IL-6 effect. As shown in Fig. 9, the first significant inhibition of $\mathrm{PGE}_{2}$ induced $\mathrm{Ca}^{2+}$ transient was observed after $8 \mathrm{~h}$ of preincubation with $200 \mathrm{U} / \mathrm{ml} \mathrm{IL-6} \mathrm{(19 \pm 2 \%}$ inhibition; $P<0.05$ vs. control). The maximum inhibitory effect of IL- 6 was observed after $48 \mathrm{~h}$ of preincubation $(65 \pm 4 \%$ inhibition; $P<0.01$ vs. control).

Effect of IL-6 on PTH dose response for $\left[\mathrm{Ca}^{2+}\right]_{i}$ rise. Fig. 10 describes the effect of preincubation with $200 \mathrm{U} / \mathrm{ml}$ IL- 6 for 24 $h$ on the dose-response relationship for PTH-mediated $\left[\mathrm{Ca}^{2+}\right]_{i}$ rise. $\mathrm{ED}_{50}$ for PTH effect was not affected by IL-6 treatment $\left(\mathrm{ED}_{50} \sim 4 \times 10^{-9} \mathrm{M}\right)$. In contrast, the maximal $\left[\mathrm{Ca}^{2+}\right]_{\mathrm{i}} \mathrm{re}-$ sponse to PTH was significantly affected by IL-6 ( 63\% reduction). Similar qualitative results were obtained when a dose-response relationship for $\mathrm{PGE}_{2}$ was studied. At a maximal dose of $50 \mu \mathrm{MPGE}$, the initial rise in $\left[\mathrm{Ca}^{2+}\right]_{\mathrm{i}}$ was $\sim 60 \%$ less in IL-6-treated cells ( $200 \mathrm{U} / \mathrm{ml}$ for $24 \mathrm{~h}$ ) compared with control. $\mathrm{ED}_{50}$ for the $\mathrm{PGE}_{2}$-stimulated $\left[\mathrm{Ca}^{2+}\right]_{\mathrm{i}}$ response was not altered by IL-6.

Effect of IL-6 on PGE $E_{2}$-stimulated 1.4.5-IP $P_{3}$ production. Since the release of $\mathrm{Ca}^{2+}$ from intracellular stores is closely linked to the inositol phosphate turnover, we next measured the effect of IL-6 on phosphatidylinositol metabolism. Fig. 11 describes the effect of IL-6 on the production of $\mathrm{IP}_{1}, \mathrm{IP}_{2}$, and $\mathrm{IP}_{3}$ mediated by $\mathrm{PGE}_{2}$ in UMR-106 cells. We used $\mathrm{PGE}_{2}$ as an agonist in this study since we have shown that in UMR-106 cells, $\mathrm{PGE}_{2}$ is a potent stimulator of $\mathrm{IP}_{3}$ generation (44). In preliminary experiments, we found a significant increase in $\mathrm{IP}_{3}$ after $10 \mathrm{~s}$ of stimulation with $\mathrm{PGE}_{2}$. After $30 \mathrm{~s}$ of stimulation, $\mathrm{IP}_{1}$ was elevated whereas $\mathrm{IP}_{3}$ was undetectable. This finding is probably related to the fact that $30 \mathrm{~s}$ is a long enough time during which $\mathrm{IP}_{3}$ is already degraded to $\mathrm{IP}_{2}$ and $\mathrm{IP}_{1}$. Based on these findings, we measured phosphoinositol production after 10-s stimulation with $\mathrm{PGE}_{2}$. As shown in Fig. 11, pretreatment of the cells with $200 \mathrm{U} / \mathrm{ml}$ IL- 6 for $24 \mathrm{~h}$ significantly inhibited the generation of inositol phosphates by $\mathrm{PGE}_{2} . \mathrm{IP}_{3}$ was $3,228 \pm 33$ and $1,830 \pm 46 \mathrm{cpm} / 10^{6}$ cells in control (vehicletreated cells) and IL-6-treated cells, respectively $(P<0.01)$. IP $P_{1}$ was $5,950 \pm 64$ and $3,740 \pm 75 \mathrm{cpm} / 10^{6}$ cells in vehicle- and IL-6-treated cells, respectively $(P<0.01)$. The initial inhibitory effect of IL- 6 was observed after $8 \mathrm{~h}$ of preincubation and 


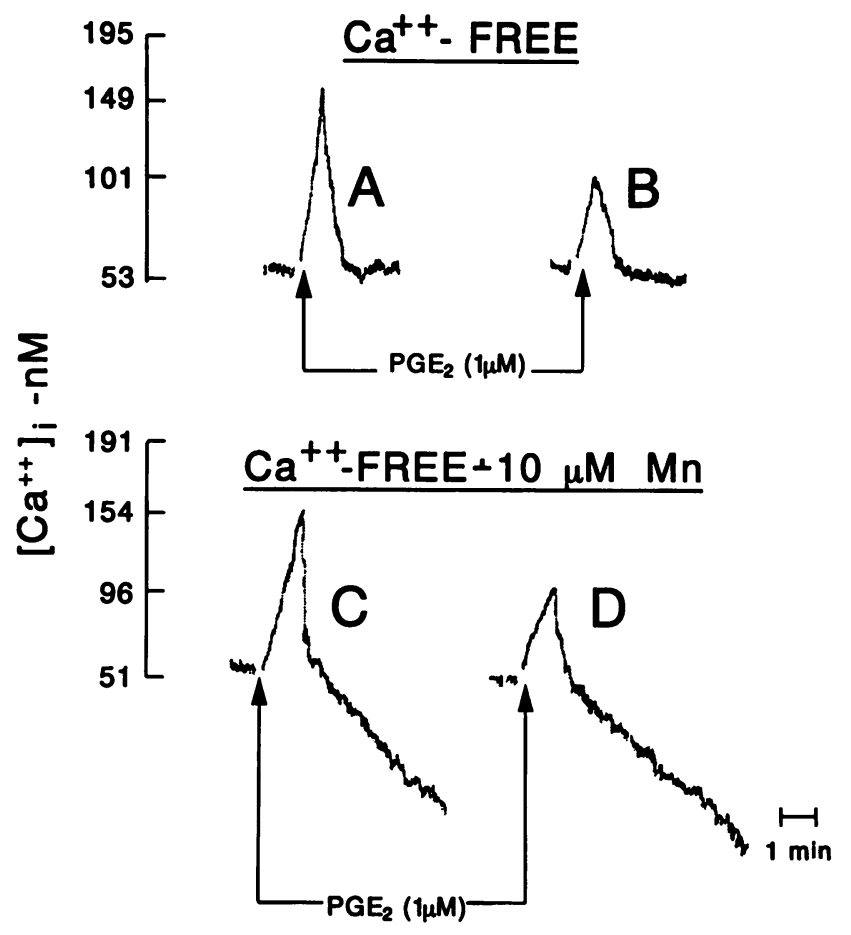

Figure 6. IL-6 effect on $\mathrm{Ca}^{2+}$ influx vs. $\mathrm{Ca}^{2+}$ release. UMR-106 cells were preincubated for $24 \mathrm{~h}$ in serum-free DME containing either vehicle alone $(A$ and $C$ ) or $200 \mathrm{U} / \mathrm{ml} \mathrm{IL-6} \mathrm{(} B$ and $D$ ). On the day of the experiment, cells were loaded with fura- 2 as described in Methods and then perfused with $\mathrm{Ca}^{2+}$-free BSS in the absence $(A$ and $B)$ or presence $(C$ and $D)$ of $10 \mu \mathrm{M} \mathrm{MnCl}_{2}$. $\mathrm{PGE}_{2}(1 \mu \mathrm{M})$ was added acutely to the cells (arrow) and fluorescence was recorded. $\left[\mathrm{Ca}^{2+}\right]_{i}$ was calculated after calibration of the signal. This experiment represents one of six similar experiments.

the overall time course corresponded to the time course of the cytokine effect on hormonally induced $\left[\mathrm{Ca}^{2+}\right]_{\mathrm{i}}$ rise. Although our experiment did not separate the different $\mathrm{IP}_{3}$ isomers, these results clearly demonstrate that IL-6 blunts the hydrolysis of phosphatidylinositols triggered by $\mathrm{PGE}_{2}$. IL-6, when used alone, did not alter the basal levels of $\mathrm{IP}_{1}$ and $\mathrm{IP}_{3}$ neither after $24 \mathrm{~h}$ of preincubation nor after an acute addition to the cells.

IL-6 effect on agonist-induced cAMP production. Since cAMP serves as another second messenger, alongside $\left[\mathrm{Ca}^{2+}\right]_{\mathrm{i}}$, mediating the effects of calciotropic hormones in bone, we studied the effect of IL-6 on agonist-mediated cAMP production. We measured cAMP production in response to $\mathrm{PTH}, \mathrm{PGE}_{2}$, forskolin and cholera toxin. Forskolin and cholera toxin were used, respectively to activate the catalytic and stimulatory $\left(G_{s}\right)$ subunit of adenylyl cyclase independent of hormonal binding to a receptor. The data presented in Table I demonstrate that IL-6 did not influence cAMP production by either receptor (PTH and PGE $_{2}$ ) or nonreceptor (forskolin and cholera toxin) mechanisms.

Effect of IL-6 on cell growth. We have recently shown that various osteotropic factors (e.g., PTH, $\mathrm{PGE}_{2}$ ) mediate their effects on osteoblast function through the $\mathrm{Ca}^{2+}$ and cAMP signaling systems $(44,56)$. Among the pleiotropic effects mediated by these messenger systems, cAMP is antiproliferative in osteoblasts whereas the $\mathrm{Ca}^{2+}$ signaling system, while not having an effect on proliferation by itself, antagonizes the antiproliferative effect of cAMP $(44,56)$. We, therefore, reasoned that

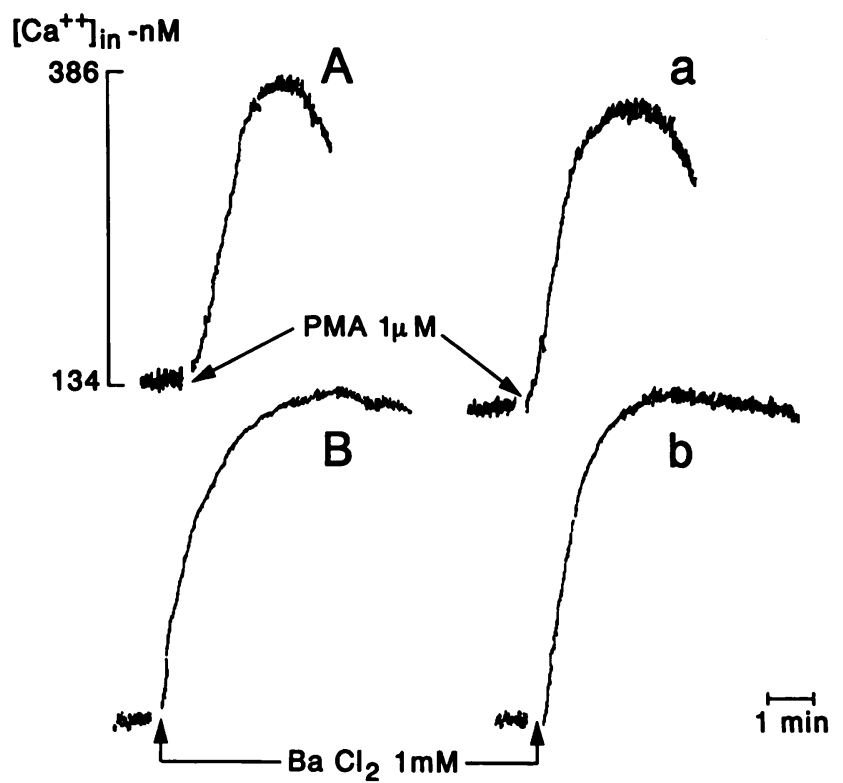

Figure 7. IL-6 effect on PKC- and depolarization-activated $\mathrm{Ca}^{2+}$ entry pathways. UMR-106 cells were cultured for $24 \mathrm{~h}$ in serum-free DME containing either vehicle alone ( $A$ and $B$ ) or $200 \mathrm{U} / \mathrm{ml} \mathrm{IL-6} \mathrm{(} a$ and $b$ ). On the day of the experiment, cells were loaded with fura-2 as described in Methods. In $A$ and $a$, cells were perfused with BSS containing $1.5 \mathrm{mM} \mathrm{CaCl}_{2}$. PMA $(1 \mu \mathrm{M})$ was added as indicated and fluorescence was recorded. In $B$ and $b$, cells were bathed in $\mathrm{Ca}^{2+}$-free BSS. After stabilization of the signal, $1 \mathrm{mM} \mathrm{BaCl}_{2}$ was added as indicated. This experiment represents one of five similar experiments.

since IL- 6 attenuates $\left[\mathrm{Ca}^{2+}\right]_{\mathrm{i}}$ rise by calciotropic hormones, it may impinge on the effects of hormones on cell proliferation. Fig. 12 demonstrates that in UMR-106 cells, $\mathrm{PGE}_{2}$ dose dependently inhibits $\left[{ }^{3} \mathrm{H}\right]$ thymidine uptake. Pretreatment for $24 \mathrm{~h}$ with $200 \mathrm{U} / \mathrm{ml} \mathrm{IL}-6$ by itself did not have an effect on cell proliferation. However, when combined with $\mathrm{PGE}_{2}$, there was a marked potentiation of the antiproliferative effect of $\mathrm{PGE}_{2}$. We compared the effect of IL-6 to that of the phorbol ester, PMA. We (44) have shown that similarly to IL-6 phorbol esters also attenuate hormonally mediated increase in $\left[\mathrm{Ca}^{2+}\right]_{\mathrm{i}}$ in osteoblasts without affecting cAMP production. As shown in Fig. 12, $10 \mathrm{nM}$ PMA, while having no effect of its own on cell proliferation, greatly enhanced the antiproliferative effect of $\mathrm{PGE}_{2}$, an effect similar to that of IL-6. The combination of IL-6 and PMA did not result in additional enhancement of $\mathrm{PGE}_{2}$ induced antiproliferation beyond that produced by each agonist alone (not shown).

The experiment described in Fig. 12 was repeated in calvarial osteoblasts. The results were qualitatively comparable to those obtained in UMR-106 cells. PGE 2 at doses of 1 and 10 $\mu \mathrm{M}$ inhibited $\left[{ }^{3} \mathrm{H}\right]$ thymidine uptake by $\sim 54 \%$ and $76 \%$, respectively (control 100\%). Pretreatment of the cells for $24 \mathrm{~h}$ with $200 \mathrm{U} / \mathrm{ml}$ IL-6 had no effect on cell proliferation but when combined with $\mathrm{PGE}_{2}$, the cytokine enhanced the antiproliferative effect of $\mathrm{PGE}_{2}$ (reduction by $75 \%$ and $92 \%$ from control at 1 and $10 \mu \mathrm{M} \mathrm{PGE}_{2}$, respectively; $P<0.01 \mathrm{PGE}_{2}$ alone vs. $\mathrm{PGE}_{2}+$ IL-6).

Table II presents data showing that IL-6 has also a potentiating effect on the antiproliferative response induced by PTH. This effect is demonstrated in UMR-106 cells as well as in primary cultured osteoblasts. 


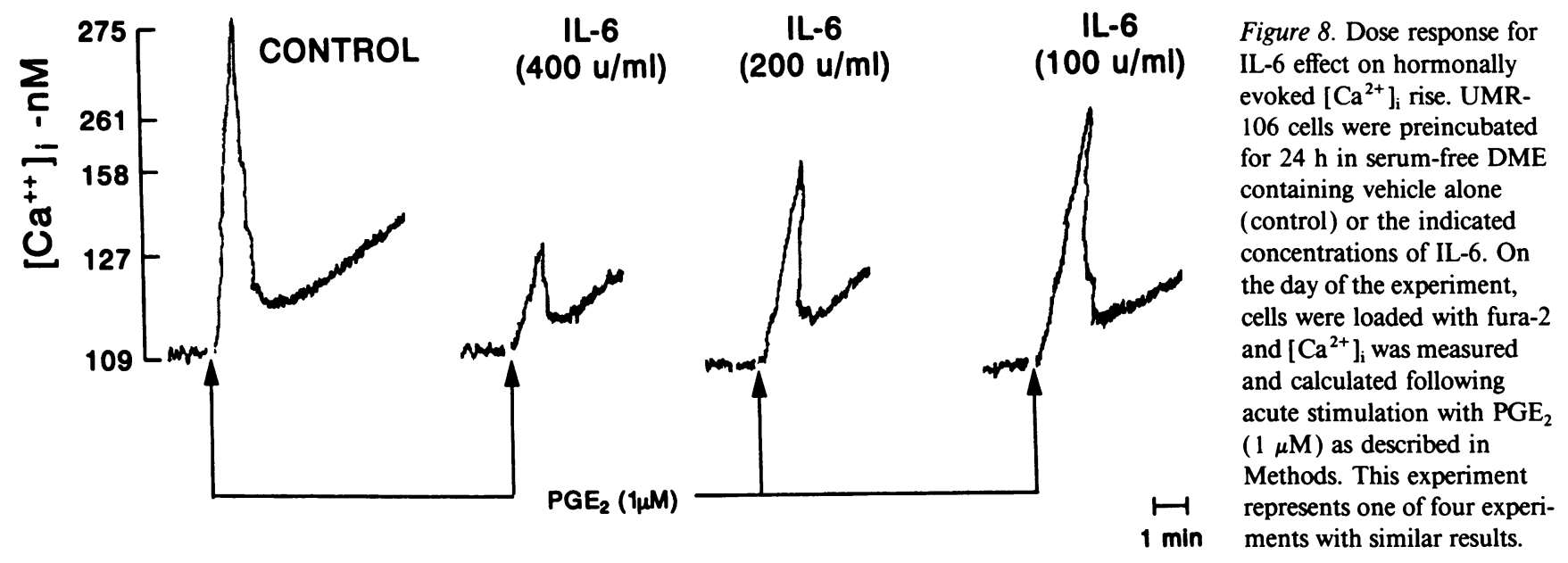

\section{Discussion}

Calciotropic hormones with bone-resorbing activity mediate their action by binding to specific receptors in osteoblasts and subsequent activation of one or both of two signal transduction pathways: $(a)$ The adenylate cyclase-cAMP system which activates protein kinase $\mathrm{A}$; and $(b)$ Elevation in $\left[\mathrm{Ca}^{2+}\right]_{\mathrm{i}}$ resulting either from opening of plasma membrane channel or from $\mathrm{Ca}^{2+}$ release after the breakdown of phosphoinositols $(44,51$, 52). Our study shows that IL-6 dissociates between the effects of calciotropic hormones $\left(\mathrm{PGE}_{2}, \mathrm{PTH}, \mathrm{ET}-1\right)$ on the $\left[\mathrm{Ca}^{2+}\right]_{i}$ and cAMP messenger systems. Thus, while not influencing any of the signal transduction pathways by itself, IL- 6 clearly attenuates the $\left[\mathrm{Ca}^{2+}\right]_{\mathrm{i}}$ response to these agonists in the osteoblastic UMR-106 cells, as well as in primary cultured osteoblasts. The cytokine affects specifically the process of $\mathrm{Ca}^{2+}$ mobilization from intracellular stores due to suppression of hormonal induced $\mathrm{IP}_{3}$ generation from phosphoinositide breakdown. In contrast, $\mathrm{Ca}^{2+}$ influx mechanisms mediated by the calciotropic hormones were not altered. Furthermore, other $\mathrm{Ca}^{2+}$ entry pathways, namely PKC and voltage activated $\mathrm{Ca}^{2+}$ channel were not also modulated by IL- 6 .

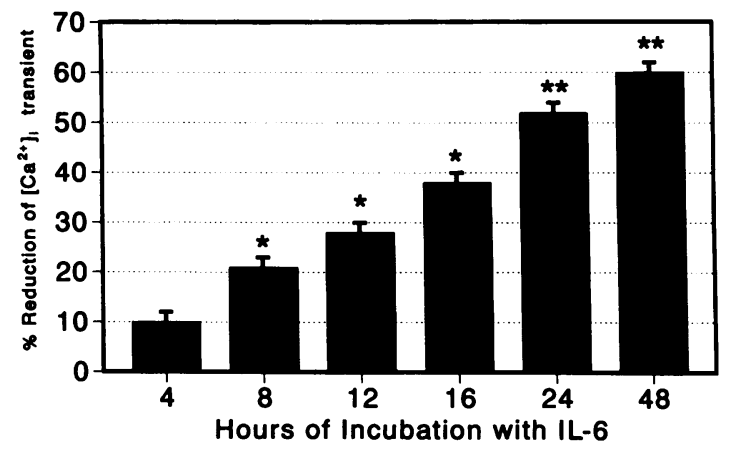

Figure 9. Time course for IL-6 effect on the $\left[\mathrm{Ca}^{2+}\right]_{\mathrm{i}}$ message. UMR106 cells were preincubated for the indicated time periods in serumfree DME containing either vehicle alone or $200 \mathrm{U} / \mathrm{ml} \mathrm{IL}-6$. At each time points, cells were loaded with fura- 2 and fluorescence was recorded after acute stimulation with $1 \mu \mathrm{M} \mathrm{PGE}_{2}$ as described in Methods. Percent inhibition of $\left[\mathrm{Ca}^{2+}\right]_{\mathrm{i}}$ increments above baseline in IL-6-treated cells vs. vehicle treated cells was calculated and plotted. Results are means \pm SE from six independent experiments. ${ }^{*} P<0.05$ IL-6-treated cells vs. control; ${ }^{* *} P<0.01$ IL-6-treated cells vs. control.
It is currently known that the biological effects of IL-6 in target organs are mediated by a specific membrane receptor (IL-6R) which belongs to cytokine receptor superfamily based on structural and functional similarities (16-22). Since the main signal transduction activated by the association of IL- 6 with its receptor involves tyrosine phosphorylation of intracellular proteins (20-22), we tested the effect of TK inhibitors on the IL-6 effects as demonstrated in our study. Our data show that herbimycin A, a highly specific inhibitor of intracellular TKs ( 53) abolished the inhibitory effect of IL-6 on hormonally induced $\mathrm{Ca}^{2+}$ transients. This effect was not shared by another TK inhibitor, tyrphostin (RG50863) which is more specific for receptor TKs (e.g., EGF receptor). Since the two TK inhibitors also differ in their ability to inhibit TK activity encoded by the $c$-src gene $(53,57)$, our data provide an indirect evidence for possible role of src TK in mediating some of IL-6 effects in osteoblasts. However, in the absence of more direct assays of src activity, the possibility of other intracellular TKs mediating

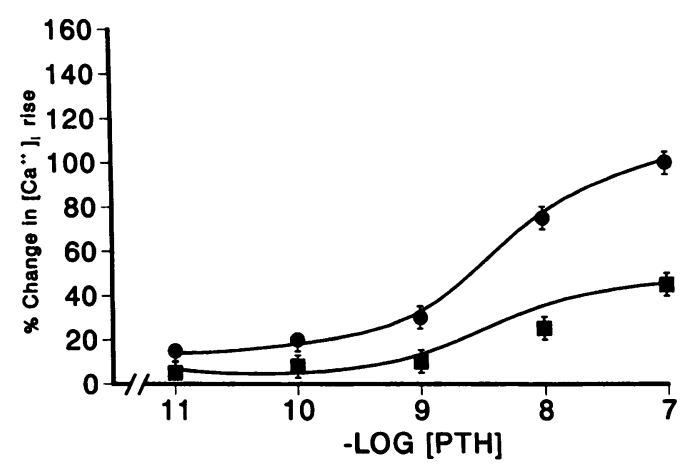

Figure 10. IL-6 effect on PTH dose-response curve for stimulation of $\mathrm{Ca}^{2+}$ transients. UMR-106 cells were preincubated for $24 \mathrm{~h}$ in serum-free DME containing either vehicle alone $(\bullet)$ or $200 \mathrm{U} / \mathrm{ml}$ IL-6 (ø). On the day of the experiment, cells were loaded with fura-2 perfused with $\mathrm{Ca}^{2+}$-replete BSS and acutely stimulated with the indicated concentrations of PTH as described in Methods. The peak rise in $\left[\mathrm{Ca}^{2+}\right]_{\mathrm{i}}$ was recorded and measured. $\left[\mathrm{Ca}^{2+}\right]_{\mathrm{i}}$ increment above resting level after stimulation with $10^{-7} \mathrm{M}$ PTH in vehicle treated cells (control) was taken as $100 \%$. At each PTH concentration, the increase in $\left[\mathrm{Ca}^{2+}\right]_{i}$ above resting level was calculated and plotted as percent relative to the $100 \%$ control. Data are mean \pm SE from four independent experiments. Curves were fit using nonlinear least square analysis. 


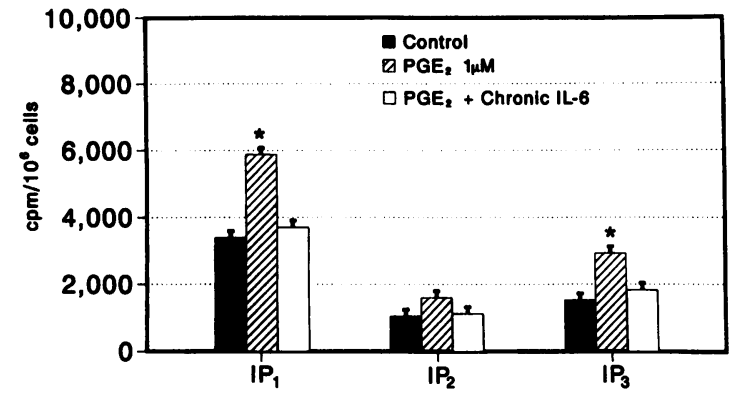

Figure 11. IL-6 effect on phosphoinositol production by $\mathrm{PGE}_{2}$. UMR-106 cells in 12-well plates were prelabeled with $3 \mu \mathrm{Ci} / \mathrm{ml}$ myo $\left[{ }^{3} \mathrm{H}\right]$ inositol as described in Methods. On the day of the experiment, cells were stimulated with $1 \mu \mathrm{M} \mathrm{PGE}_{2}$ for $10 \mathrm{~s}$. Reaction was terminated with trichloroacetic acid and inositol phosphates $\mathrm{IP}_{1}, \mathrm{IP}_{2}$, and $\mathrm{IP}_{\mathbf{3}}$ were separated on AG-1X8 columns as described in Methods. The experiment was performed under the following three conditions: (a) control (no hormone added); (b) cell preincubated for $24 \mathrm{~h}$ with IL-6 vehicle followed by acute ( $10 \mathrm{~s}$ ) stimulation with $\mathrm{PGE}_{2} ;(c)$ cells preincubated for $24 \mathrm{~h}$ with $200 \mathrm{U} / \mathrm{ml} \mathrm{IL-6}$ followed by acute ( $10 \mathrm{~s}$ ) exposure to $\mathrm{PGE}_{2}$. Values are mean $\pm \mathrm{SE}(n=4)$ from three independent experiments. ${ }^{*} P<0.01$ vs. control and IL-6-treated cells.

IL-6 effect cannot be excluded. Recently, herbimycin A has been shown to inhibit bone resorption, both in vivo and in vitro through a direct effect on osteoclast number and function (57). Our data, therefore, indicate that this drug can also affect bone metabolism through action in osteoblasts as well. The link between activation of TK and suppression of hormonal induced $\mathrm{Ca}^{2+}$ signals remains conjectural at this point. It could be related to tyrosine phosphorylation of certain phosphoinositides which, in turn, could reduce the level of substrate for $\mathrm{IP}_{3}$. This possibility awaits further exploration.

The physiological significance of the IL- 6 effect on agonist induced $\left[\mathrm{Ca}^{2+}\right]_{\mathrm{i}}$ rise is demonstrated by our data showing that IL-6, while having no effect of its own on cell proliferation, potentiates the antiproliferative effect of $\mathrm{PGE}_{2}$ and $\mathrm{PTH}$ in

Table I. IL-6 Effect on Agonist-induced cAMP Production

\begin{tabular}{llc}
\hline & \multicolumn{2}{c}{ cAMP accumulation } \\
\cline { 2 - 3 } \multicolumn{1}{c}{ Agonist } & $\begin{array}{c}\text { Vehicle } \\
\text { (control) }\end{array}$ & $\begin{array}{c}\text { IL-6 } \\
(200 \mathrm{U} / \mathrm{ml})\end{array}$ \\
& \multicolumn{2}{c}{ (pmol/10 cells) } \\
PTH $\left(10^{-8} \mathrm{M}\right)$ & $231 \pm 12$ & $229 \pm 11$ \\
PGE $\left(10^{-6} \mathrm{M}\right)$ & $234 \pm 18$ & $231 \pm 9$ \\
Forskolin $(15 \mu \mathrm{M})$ & $344 \pm 19$ & $348 \pm 25$ \\
Cholera toxin $(5 \mu \mathrm{g} / \mathrm{ml})$ & $137 \pm 9$ & $123 \pm 14$ \\
& & \\
\hline
\end{tabular}

Confluent UMR-106 cells grown in 24-well plates were incubated for $24 \mathrm{~h}$ in serum-free DMEM containing vehicle or $200 \mathrm{U} / \mathrm{ml} \mathrm{IL-6}$. On the day of the experiment, cells were stimulated with the following agonists: (1-34) b PTH $10^{-8} \mathrm{M}$ for $5 \mathrm{~min}$. $\mathrm{PGE}_{2} 1 \mu \mathrm{M}$ for $5 \mathrm{~min}$. Forskolin $15 \mu \mathrm{M}$ for $5 \mathrm{~min}$ and cholera-toxin $(5 \mu \mathrm{g} / \mathrm{ml})$ for $2 \mathrm{~h}$. The reaction was terminated by aspirating the medium containing the agonist and adding $0.5 \mathrm{ml}$ of L-propanol. Total cAMP accumulation was measured in the medium and in the propanol extract as described in Methods. Results show mean $\pm \operatorname{SE}(n=4)$ from four independent experiments. Similar results were obtained when IL- 6 was added to cells $15 \mathrm{~min}$ or $2 \mathrm{~h}$ before exposure to the various agonists.

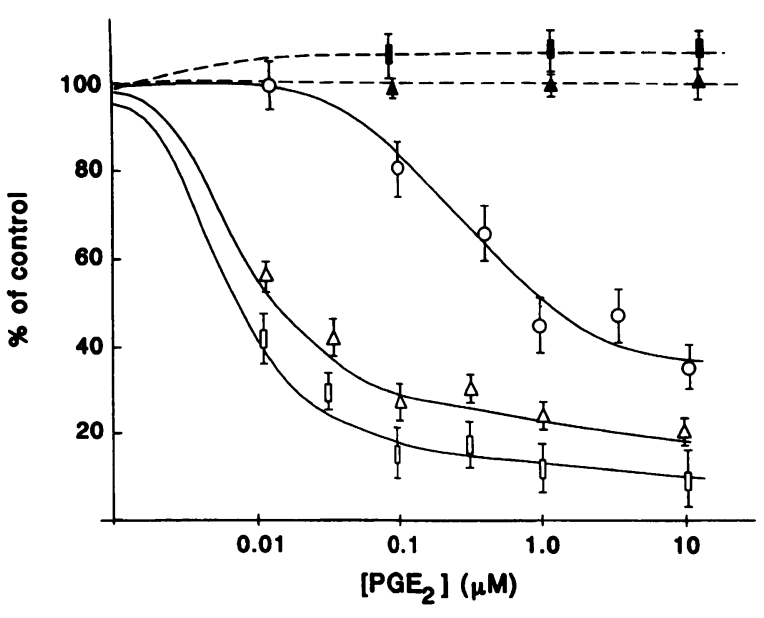

Figure 12. IL-6 potentiates the antiproliferative effect of $\mathrm{PGE}_{2}$. UMR-106 cells grown in 24-well plates were preincubated for $24 \mathrm{~h}$ in serum-free DME containing: (a) different concentrations of $\mathrm{PGE}_{2}$ as indicated (o); (b) $\mathrm{PGE}_{2}$ at the different concentrations with 200 U/ml IL-6 ( $\square$ ); (c) $10 \mathrm{nM}$ PMA added to PGE 2 ( $\Delta$ ) (both IL-6 and PMA were added $15 \mathrm{~min}$ before the addition of $\mathrm{PGE}_{2}$ and were then kept for the entire 24-h incubation period with $\left.\mathrm{PGE}_{2}\right) ;(d) 200 \mathrm{U} / \mathrm{ml}$ IL-6 ( $)$; (e) $10 \mathrm{nM}$ PMA ( $\Delta) .3 \mathrm{~h}$ before the harvest, cells were pulsed with $\left[{ }^{3} \mathrm{H}\right]$ thymidine and at the end of the incubation period, $\left[{ }^{3} \mathrm{H}\right]$ thymidine uptake was done as described in Methods. Results are expressed as percent uptake relative to $100 \%$ control $\left(\left[{ }^{3} \mathrm{H}\right]-\right.$ thymidine uptake where no agonist was added). DMSO (the PMA vehicle) did not have any effect on uptake. Data are mean $\pm S E$ $(n=4)$ from five independent experiments.

osteoblasts. Others and we have shown that the pleiotropic functions of these hormones on bone metabolism can be explained on the basis of antagonistic effects between the $\mathrm{Ca}^{2+}$ and cAMP signaling pathways $(41-44,56)$. With respect to cell growth, the cAMP messenger system is antiproliferative, while $\left[\mathrm{Ca}^{2+}\right]_{\mathrm{i}}$, although having no effect of its own on cell growth, antagonizes the cAMP antiproliferative effect $(44,56)$. Thus, agonists attenuating $\left[\mathrm{Ca}^{2+}\right]_{i}$ response stimulated by PTH or $\mathrm{PGE}_{2}$ will potentiate the antiproliferative effects of these hor-

Table II. Effect of IL-6 on PTH-induced Antiproliferative Response

\begin{tabular}{lcc}
\hline & \multicolumn{2}{c}{$\left[{ }^{3} \mathrm{H}\right]$ Thymidine uptake } \\
\cline { 2 - 3 } \multicolumn{1}{c}{ Addition } & \multicolumn{2}{c}{$\mathrm{cpm} /$ well } \\
& UMR-106 cells & Calvarial osteoblasts \\
Vehicle (control) & $13410 \pm 380$ & $8507 \pm 87$ \\
PTH $\left(10^{-8} \mathrm{M}\right)$ & $6208 \pm 75^{*}$ & $2515 \pm 54^{*}$ \\
PTH $\left(10^{-9} \mathrm{M}\right)$ & $8205 \pm 92^{*}$ & $3897 \pm 35^{*}$ \\
IL-6 $(200 \mathrm{U} / \mathrm{ml})$ & $13727 \pm 415$ & $8620 \pm 112$ \\
IL-6 + PTH $\left(10^{-8} \mathrm{M}\right)$ & $3708 \pm 56^{\ddagger}$ & $1863 \pm 42^{\ddagger}$ \\
IL-6 + PTH $\left(10^{-9} \mathrm{M}\right)$ & $5247 \pm 63^{\ddagger}$ & $2456 \pm 64^{\ddagger}$ \\
\end{tabular}

UMR-106 cells or primary osteoblastic cells from neonatal rat calvariae were cultured for $24 \mathrm{~h}$ in serum-free media containing additives as indicated. At the end of the incubation period, thymidine incorporation was performed as described in Methods. Data are mean $\pm \mathrm{SE}$ ( $n$ $=4$ ) from three independent experiments. ${ }^{*} P<0.01$ vs. control; ${ }^{\ddagger} P<0.005$ vs. control; $P<0.05$ vs. PTH alone (i.e., without IL-6). 
mones (44) while agents enhancing $\left[\mathrm{Ca}^{2+}\right]_{\mathrm{i}}$ response will mitigate the antiproliferative effects of the hormones (56). Our data, therefore, suggest that by attenuating $\left[\mathrm{Ca}^{2+}\right]_{i}$ rise induced by $\mathrm{PGE}_{2}$ and PTH (which activate both second messengers), IL-6 further enhances the antiproliferative effect of these hormones. Consistent with this notion, our data have shown that IL-6 effect was similar to that of PMA which also potentiates the antiproliferative effect of $\mathrm{PGE}_{2}$ through the same mechanism, namely, attenuation of $\mathrm{Ca}^{2+}$ signals induced by calciotropic hormones (44). The enhancing influence of IL-6 on the antimitotic effect of hormones could not be ascribed to increased cAMP levels since IL-6 does not modify cAMP production in osteoblasts (Table I).

Our study adds to the overall gamut of IL-6 effects on bone metabolism. The majority of evidence currently available suggests that IL- 6 stimulates bone resorption by enhancing osteoclast recruitment from hematopoietic precursors $(23,25,28$, 29). However, the data regarding IL-6 effect on the osteoblast have, thus far, yielded conflicting results. While some investigators have shown modest effect of the cytokine on cell proliferation (37) and differentiation (23), others have failed to demonstrate IL-6 effect on proliferation, alkaline phosphatase activity, or osteocalcin production in osteoblastic cells (36). However, even in cells in which IL-6 has been shown to exert no effect (such as human osteoblastic cells and ROS 17/2.8 cells [36]), the cells produce IL-6 and also express mRNA for the IL-6 receptor (36). Based on our data, we suggest that IL-6 has a paracrine/autocrine role, whereby after its secretion from the osteoblast in response to calciotropic hormones, IL-6 feeds back on the osteoblast to modulate signaling pathways generated by the hormones. This, in turn, will affect osteoblastic function (e.g., cell proliferation). In addition, IL-6 acts on hematopoietic progenitors to recruit osteoclasts thereby stimulating bone resorption.

\section{Acknowledgments}

The authors would like to thank Deborah J. Stauber for technical support and Marie Trnka for excellent secretarial assistance in the preparation of the manuscript.

This work was supported by an institutional grant from the National Kidney Foundation of S. California and by the Max Factor Family Foundation.

\section{References}

1. Kishimoto, T., and T. Hirano. 1988. Molecular regulation of B lymphocyte response. Annu. Rev. Immunol. 6:485-512.

2. Van Snick, J. 1990. Interleukin-6: an overview. Annu. Rev. Immunol. 8:253-278.

3. Nordan, R. P., M. Potter. 1986. A macrophage-derived factor required by plasmacytomas for survival and proliferation in vitro. Science (Wash. DC). 233:566-569.

4. Van Damme, J., G. Opdenakker, R. J. Simpson, M. R. Rubira, S. Cayphas, A. Vink, A. Billiau, and J. Van Snick. 1987. Identification of the human 26-kD protein; interferon $\mathbf{B}_{2}$ (IFN-B B $_{2}$ as a $\mathbf{B}$ cell hybridoma/plasmacytoma growth factor induced by interleukin 1 and tumor necrosis factor. J. Exp. Med. 165:914919.

5. Kawano, M., T. Hirano, T. Matsuda, Y. Horii, K. Iwato, H. Asaoku, B. Tang, O. Tanabe, H. Tanaka, A. Kuramoto, et al. 1988. Autocrine generation and requirement of BSF-2/IL-6 for human multiple myelomas. Nature (Lond.). 332:83-85.

6. Garman, R. D., K. A. Jacobs, S. C. Clark, and D. H. Raulet. 1987. B-cell stimulatory factor 2 (B2 interferon) functions as a second signal for interleukin 2 production by mature murine T cells. Proc. Natl. Acad. Sci. USA. 84:7629-7633.

7. Ikebuchi, K., G. G. Wong, S. C. Clark, J. N. Ihle, Y. Hirai, and M. Ogawa. 1987. Interleukin 6 enhancement of interleukin 3-dependent proliferation of multipotential hemopoietic progenitors. Proc. Natl. Acad. Sci. USA. 84:90359039.

8. Lotz, M., F. Jirik, P. Kabouridis, C. Tsoukas, T. Hirano, T. Kishimoto, and D. A. Carson. 1988. B-cell stimulating factor/interleukin 6 is a co-stimulant for human thymocytes and T lymphocytes. J. Exp. Med. 167:1253-1258.

9. Tosato, G., K. B. Seamon, N. D. Goldman, P. B. Sehgal, L. T. May, G. C. Washington, K. D. Jones, and S. E. Pike. 1988. Monocyte-derived human B-cell growth factor identified as interferon-B2 (BSF-2, IL-6). Science (Wash. DC). 239:502-504.

10. Hirano, T., T. Taga, N. Nakano, K. Yasukawa, S. Kashiwamura, K. Shimizu, K. Nakajima, K. H. Pyun, and T. Kishimoto. 1985. Purification to homogeneity and characterization of human B-cell differentiation factor (BCDF or BSFp-2). Proc. Natl. Acad. Sci. USA. 82:5490-5494.

11. Miyaura, C., K. Onozaki, Y. Akiyama, T. Taniyama, T. Hirano, T. Kishimoto, and T. Suda. 1988. Recombinant human IL-6 (B-cell stimulatory factor 2 ) is a potent inducer of differentiation of mouse myeloid leukemia cells (M1). FEBS (Fed. Eur. Biochem. Soc.) Lett. 234:17-21.

12. Muraguchi, A., T. Hirano, B. Tang, T. Matsuda, Y. Horii, K. Nakajima and T. Kishimoto. 1988. The essential role of B cell stimulatory factor 2 (BSF-2/ IL-6) for the terminal differentiation of B cells. J. Exp. Med. 167:332-344.

13. Okada, M., M. Kitahara, S. Kishimoto, T. Matsuda, T. Hirano, and T. Kishimoto. 1988. IL-6/BSF-2 functions as a killer helper factor in the in vitro induction of cytotoxic T cells. J. Immunol. 141:1543-1549.

14. Satoh, T., S. Nakamura, T. Taga, T. Matsuda, T. Hirano, T. Kishimoto, and Y. Kaziro. 1988. Induction of neuronal differentiation in PC12 cells by B-cell stimulatory factor 2/interleukin-6. Mol. Cell. Biol. 8:3546-3549.

15. Gauldie, J., C. Richards, D. Harnish, P. Lansdorp, and H. Baumann. 1987. Interferon B2/BSF-2 shares identity with monocyte derived hepatocyte stimulating factor (HSF) and regulates the major acute phase protein response in liver cells. Proc. Natl. Acad. Sci. USA. 84:7241-7255.

16. Taga, T., Y. Kawanishi, R. R. Hardy, T. Hirano, and T. Kishimoto. 1987. Receptors for B cell stimulatory factor 2: quantitation, specificity, distribution, and regulation of their expression. J. Exp. Med. 166:967-981.

17. Chiu, C. P., C. Moulds, R. L. Coffman, D. Rennick, and F. Lee. 1988. Multiple biological activities are expressed by a mouse interleukin $6 \mathrm{cDNA}$ clone isolated from bone marrow stromal cells. Proc. Natl. Acad. Sci. USA. 85:70997103.

18. Hirano, T., K. Yasukawa, H. Harada, T. Taga, Y. Watanabe, T. Matsuda, S. Kashiwamura, K. Nakajima, K. Koyama, A. Iwamatsu, et al. 1986. Complementary DNA for a novel human interleukin (BSF-2) that induces B lymphocytes to produce immunoglobulin. Nature (Lond.). 324:73-76.

19. Yamasaki, T., T. Taga, Y. Hirata, H. Yawata, Y. Kawanishi, B. Seed, T. Taniguchi, T. Hirano, and T. Kishimoto. 1988. Cloning and expression of the human interleukin-6 (BSF-2/IFN-B2) receptor. Science (Wash. DC). 241:825828.

20. Taga, T., M. Hibi, Y. Hirata, K. Yamasaki, K. Yasukawa, T. Matsuda, K. T. Hirano, and T. Kishimoto. 1989. Interleukin-6 triggers the association of its receptor with a possible signal transducer, gp130. Cell. 58:573-581.

21. Davis, S., T. H. Aldrich, N. Stahl, L. Pan, T. Taga, T. Kishimoto, N. Y. I., and G. D. Yancopoulos. 1993. LIFR $\beta$ and gp 130 as heterodimerizing signal transducers of the tripartite CNTF receptor. Science (Wash. DC). 260:18051808.

22. Murakami, M., M. Hibi, N. Nakagawa, T. Nakagawa, K. Yasukawa, K. Yamanishi, T. Taga, and T. Kishimoto. 1993. IL-6-induced homodimerization of $\mathrm{gp} 130$ and associated activation of a tyrosine kinase. Science (Wash. DC) 260:1808-1810.

23. Ishimi, Y., C. Miyaura, C. H. Jin, T. Akatsu, E. Abe, Y. Nakamura, A. Yamaguchi, S. Yoshiki, T. Matsuda, T. Hirano, et al. 1990. IL-6 is produced by osteoblasts and induces bone resorption. J. Immunol. 145:3297-3303.

24. Feyen, J. H. M., P. Elford, F. E. Ki Padova, and U. Trechsel. 1989. Interleukin- 6 is produced by bone and modulated by parathyroid hormone. $J$. Bone Miner. Res. 4:633-638.

25. Lowik, C. W. G. M., G. Van der Pluijm, S. Bloys, K. Hoekman, O. L. M. Bivoet, L. A. Aarden, and S. E. Papapoulos. 1989. Parathyroid hormone (PTH) and PTH-like protein (PLP) stimulate interleukin-6 production by osteogenic cells: a possible role of interleukin-6 in osteoclastogenesis. Biochem. Biophys. Res. Commun. 162:1546-1552.

26. Linkhart, T. A., S. G. Linkhart, D. C. MacCharles, D. L. Long, and D. D. Strong. 1991. Interleukin-6 messenger RNA expression and interleukin-6 protein secretion in cells isolated from normal human bone: regulation by interleukin-1 . J. Bone Miner. Res. 61:1285-1294.

27. Manolagas, S. C., and R. L. Jilka. 1992. Cytokines, hematopoiesis, osteoclastogenesis, and estrogens. Calif. Tissue Int. 50:199-202.

28. Roodman, G. D. 1992. Interleukin-6: an osteotropic factor? J. Bone Miner. Res. 7:475-478.

29. Kurihara, N., D. Bertolini, T. Suda, Y. Akiyama, G. D. Roodman. 1990. Interleukin-6 stimulates osteoclast-like multinucleated cell formation in long term human marrow cultures by inducing IL-1 release. J. Immunol. 144:426430.

30. Al-Humidan, A., S. H. Ralston, D. E. Hughes, K. Chapman, L. Aarden, 
R. Graham, G. Russell, M. Gowen. 1991. Interleukin-6 does not stimulate bone resorption in neonatal mouse calvariae. J. Bone Miner. Res. 6:3-8.

31. Barton, B. E., and R. Mayer. 1990. IL-3 and IL-6 do not induce bone resorption in vitro. Cytokine. 2:217-220.

32. Hirano, T., T. Matsuda, M. Turner, N. Miyasaka, G. Buchan, B. Tang, K Sata, M. Shimizu, R. Maini, M. Feldman, and T. Kishimoto. 1988. Excessive production of interleukin $6 / \mathrm{B}$ cell stimulatory factor-2 in rheumatoid arthritis. Eur. J. Immunol. 18:1797-1801.

33. Girasole, G., R. J. Jilka, G. Passeri, S. Baswell, G. Boder, D. C. Williams, and S. C. Manolagas. 1992. 17 $\beta$-Estradiol inhibits interleukin-6 production by bone marrow-derived stromal cells and osteoblasts in vitro: a potential mechanism for the antiosteoporotic effect of estrogens. J. Clin. Invest. 89:883-891.

34. Jilka, R. L., G. Hangoc, G. Girasole, G. Passeri, D. C. Williams, J. S. Abrams, B. Boyce, H. Broxmeyer, and S. C. Manolagas. 1992. Increased osteoclast development after estrogen loss: mediation by interleukin-6. Science (Wash. DC). 257:88-91.

35. Roodman, G. D., N. Kurihara, Y. Ohsaki, T. Kukita, D. Hosking, A. Demulder, and F. S. Singer. 1992. Interleukin-6: a potential autocrine/paracrine factor in Paget's disease of bone. J. Clin. Invest. 89:46-52.

36. Littlewood, A. J., L. A. Aarden, D. B. Evans, R. G. G. Russell, and M. Gowen. 1991. Human osteoblastlike cells do not respond to interleukin-6. J. Bone Miner. Res. 6:141-148.

37. Fang, M. A., and T. J. Hahn. 1991. Effects of interleukin-6 on cellular function in UMR-106-01 osteoblast like cells. J. Bone Miner. Res. 6:133-139.

38. Hughes, F. J., and G. L. Howells. 1993. Interleukin-6 inhibits bone formation in vitro. Bone Miner. 21:21-28.

39. Rodan, G. A., and T. J. Martin. 1981. Role of osteoblasts in hormonal control of bone resorption-a hypothesis. Calcif. Tissue Int. 33:349-351.

40. McSheehy, P. M. J., and T. J. Chambers. 1986. Osteoblast-like cells in the presence of parathyroid hormone release soluble factor that stimulates osteoclastic bone resorption. Endocrinology. 119:1654-1659.

41. Herrmann-Erlee, M. P. M., and J. M. Meer. 1974. The effects of dibutyryl cyclic AMP aminophylline and propranolol on PTE induced bone resorption "in vitro". Endocrinology. 94:414-434.

42. Ivey, J. L., D. R. Wright, and A. H. Tashjian. 1976. Bone resorption in organ culture. Inhibition by the divalent cation ionophores A23187 and X537A J. Clin. Invest. 58:1327-1338.

43. Green, J., C. R. Kleeman, S. Schotland, and C. Chaimovitz. 1991. Acute phosphate depletion dissociates hormonal stimulated second messengers in osteoblast-like cells. Endocrinology. 129:848-858.

44. Yamaguchi, D. T., T. J. Hahn, T. G. Beeker, C. R. Kleeman, and S.
Muallem. 1988. Relationship of cAMP and calcium messenger systems in prostaglandin-stimulated UMR-106 cells. J. Biol. Chem. 263:10745-10753.

45. Partridge, N. C., D. Alcorn, V. P. Michelangeli, G. Ryan, and T. J. Martin. 1983. Morphological and biochemical characterization of four clonal osteogenic sarcoma cells of rat origin. Cancer Res. 43:4308-4312.

46. Ecarot-Charrier, B., F. H. Glorieux, M. van der Rest, and G. Perreira. 1983. Osteoblasts isolated from mouse calvaria initiate matrix mineralization in culture. J. Cell Biol. 96:639-643.

47. Grynkiewicz, G., M. Peonie, R. Y. Tsien. 1985. A new generation of $\mathrm{Ca}^{2+}$ indicators with greatly improved fluorescence properties. J. Biol. Chem. 260:3340-3450.

48. Berridge, M. J., J. P. Heslop, R. F. Irvine, and K. D. Brown. 1984. Inositol triphosphate formation and calcium mobilization in Swiss 3T3 cells in response to platelet-derived growth factor. Biochem. J. 222:195-201.

49. Yamaguchi, D. T., J. Green, C. R. Kleeman, and S. Muallem. 1989. Properties of the depolarization activated calcium and barium entry in osteoblast-like cells. J. Biol. Chem. 264:197-204.

50. Yamaguchi, D. T., C. R. Kleeman, and S. Muallem. 1987. Protein kinase C-activated calcium channel in the osteoblast-like clonal osteosarcoma cell line UMR-106. J. Biol. Chem. 262:14967-14973.

51. Civitelli, R., I. R. Reid, S. Westbrook, L. V. Avioli, and K. A. Hruska 1988. Parathyroid hormone elevates inositol polyphosphates and diacylglycerol in a rat osteoblast-like cell line. Am. J. Physiol. 255:E660-E667.

52. Takuwa, Y., Y. Ohue, N. Takuwa, and K. Yamashita. 1989. Endothelinactivates phospholipase $\mathrm{C}$ and mobilizes $\mathrm{Ca}^{2+}$ from extra- and intracellular pools in osteoblastic cells. Am. J. Physiol. 257:E797-E803.

53. Uehara, Y., and H. Fukazawa. 1991. Use and selectivity of herbimycin A as inhibitor of protein-tyrosine kinase. Methods Enzymol. 201:370-379.

54. Lyall, R. M., A. Zilberstein, A. Gazit, C. Gilon, A. Levitzki, and J. Schlessinger. 1989. Tyrphostins inhibit epidermal growth factor (EGF)-receptor tyrosine kinase activity in living cells and EGF-stimulated cell proliferation. J. Biol. Chem. 264:14503-14509.

55. Simpson, A. W., A. Stampfl, and C. C. Ashley. 1990. Evidence for receptor-mediated bivalent-cation entry in A 10 vascular smooth-muscle cells. Biochem. J. 267:277-280.

56. Yamaguchi, D. T., J. Green, C. R. Kleeman, and S. Muallem. 1991. Prostaglandins enhance parathyroid hormone-evoked increase in free cytosolic calcium concentration in osteoblast-like cells. Cell Calcium. 12:609-622.

57. Yoneda, T., C. Lowe, C. H. Lee, G. Gutierrez, M. Niewolna, P. J. Williams, E. Izbicka, Y. Uehara, and G. R. Mundy. 1993. Herbimycin A, a pp60 tyrosine kinase inhibitor, inhibits osteoclastic bone resorption in vitro and hypercalcemia in vivo. J. Clin. Invest. 91:2791-2795. 